IMAGE EVALUATION

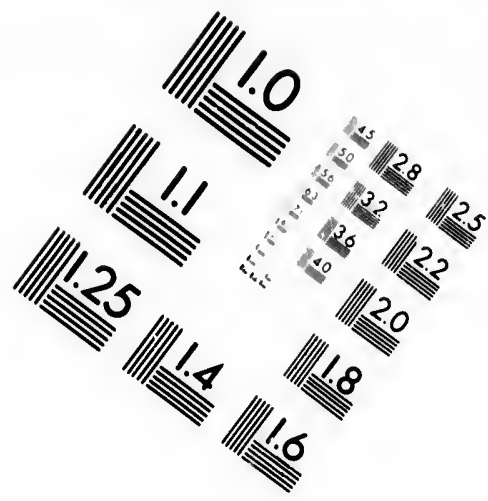

TEST TARGET (MT-3)
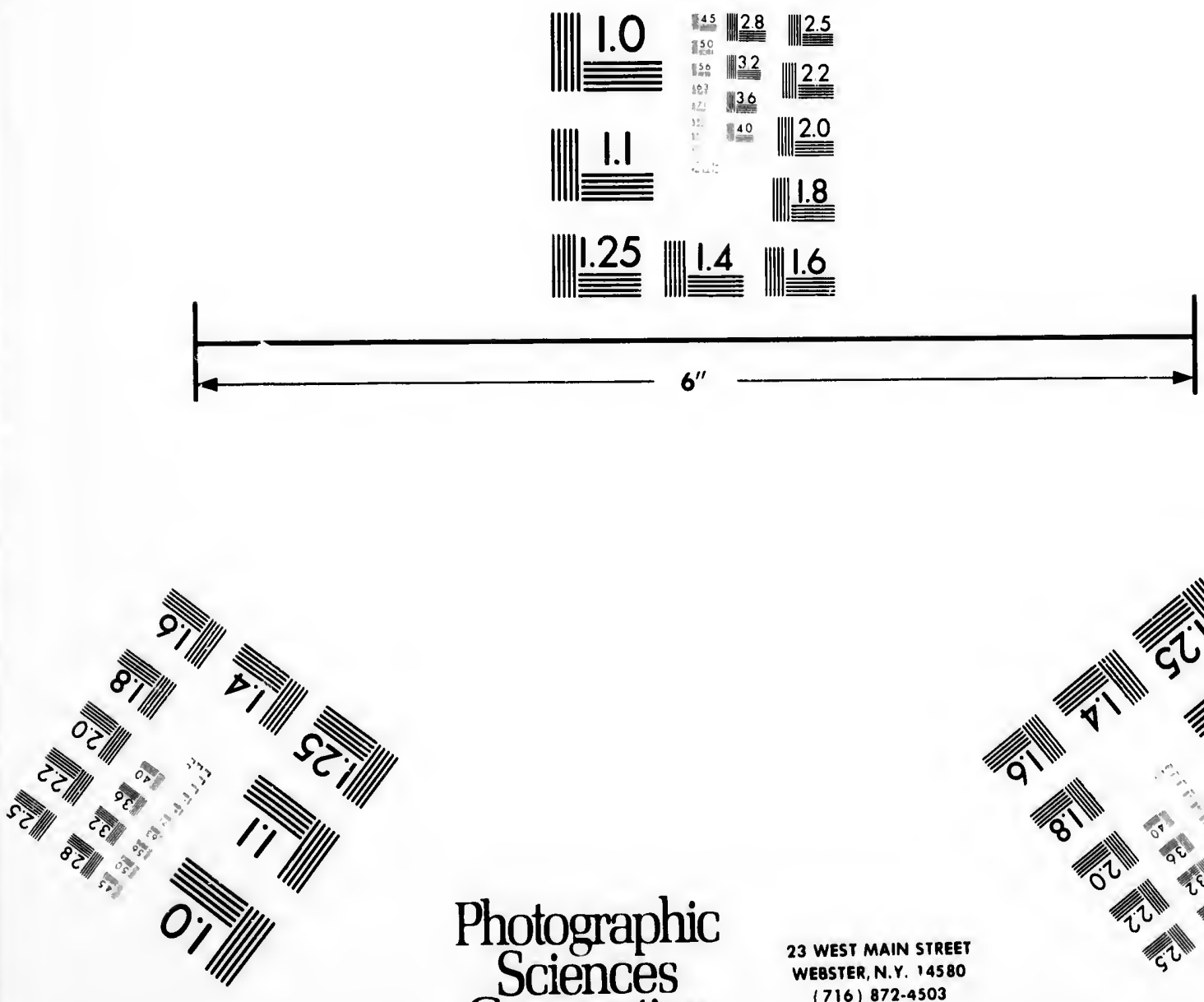

Photographic Sciences Corporation
23 WEST MAIN STREET

WEBSTER, N.Y. 14580 (716) 872-4503

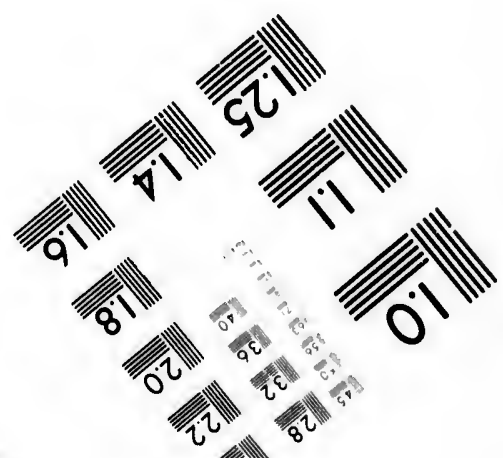

i 


\section{CIHM/ICMH Microfiche Series. \\ CIHM/ICMH Collection de microfiches.}


The Institute hes attempted to obtain the best original copy available for filming. Features of this copy which may be bibliographic, lly unique, which may alter any of the images in the reproduction, or which may significantly change the usual method of filming, are checked below.

Coloured covers/

Coliverture de couleur

\section{Covers damaged/}

Couverture endommagée

Covers restored and/or laminated/

Couverture restaurée et/ou pelliculée

Cover title missing/

Le titre de couverture menque

Coloured maps/

Cartes géographiques en couleur

Coloured ink (i.e. other than blue or black)/

Encre de couleur (i.e. autre que bleue ou noire)

Coloured plates and/or illustrations/

Planches et/ou illustrations en couleur

Bound with other material/

Relié avec d'autres documents

Tight binding may cause shadows or distortion along interior margin/

La reliure serrée peut causer de l'ombre ou de la distortion le long de la marge intérieure

Blank leaves added during restoration may appear within the text. Whenever possible, these have been omitted from filming/

II se peut que certaines pages blanches ajoutées lors d'une restauration apparaissent dans le texte, mais, lorsque cela était possible, ces pages n'ont pas été filmées.

\section{Additional comments:/}

Commentaires sispplémentaires:
L'Institut a microfilmé le meilleur exempleire qu'il lui a été possible de se procurer. Les détails de cet exemplaire qui sont peut-être uniques du point de vue blbliographique, qui peuvent modifier une image reproduite, ou qui peuvent exiger une modification dans la méthode normale de filmage sont indiqués ci-dessous.

\section{Coloured pages/}

Pages de couleur

Pages damaged/

Pages endommagées

Pages restored and/or laminated/

Pages restaurées et/ou pelliculées

Pages discoloured, stained or foxed/

Pages décolorées, tachetées ou piquées

Pages detached/

Pages détachées

Showthrough/

Transparence

Quality of print varies/

Qualité inégale de l'impression

Includes supplementary material/

Comprend du matériel supplémentaire

Only edition available/

Seule édition disponible

Pages wholly or partially obscured by errata slips, tissues, etc., have been refilmed to ensure the best possible image/

Les pages totalement ou partiellement obscurcies par un feuillet d'errata, une pelure, etc., ont été filmées à nouveau de façon à obtenir la meilleure image possible.

This item is filmed at ths reduction ratio checked below/ Ce document est filmé au taux de réduction indiqué ci-dessous.

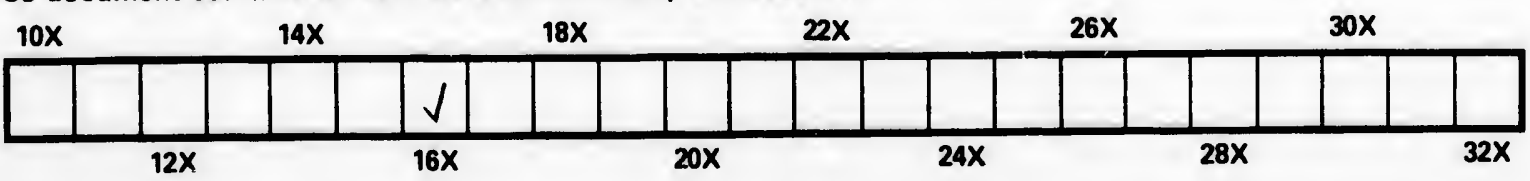


The copy filmed here has been reproduced thanks to the generosity of:

\section{National Library of Canada}

The images eppearing here are the best quality possible considering the condition and legibility of the originel copy and in keeping with the filming contract specifications.

Original copies in printed peper covers are filmed beginning with the front cover and ending on the last page with a printed or illustrated impression, or the beck cover when eppropriate. All other original copies are filmed beginning an the first page with a printed or illusirated impression, and ending on the last page with a printed or illustrated impression.

The last recorded freme on each microfiche shall contain the symbol $\longrightarrow$ Imeaning "CONTINUED"), or the symbol $\nabla$ (meaning "END"). whichever applies.

Maps, plates, charts, etc., may be filmed at different reduction ratios. Those too large to be entirely included in one exposure are filmed beginning in the upper left hand corner, left to right and top to bottom, as many frames as required. The following diagrams illustrate the method:
L'exemplaire filmé fut reproduit grâce à la générosité de:

Bibliotheqque nationale du Canada

L.3s images suivantes ont été reproduites avec le plus grand soin, compte tenu de la condition et de la netteté de l'exempleire filmé, et en conformité avec les conditions du contrat de filmage.

Les exemplaires originaux dont la couverture en papier est imprimiée sont filmés en commençant par le premier plat et en terminant soit par la derniére page qui comporte une empreinte d'impression ou d'illustration, soit par le second plat, selon le ces. Tous les autres exemplaires originaux sont filmés en commençant par la premiére page qui comporte une empreinte d'impression ou d'illustration et en tarminant par la derniére page qui comporte une telle empreinte.

Un des symboles suivants apparaîtra sur la dernière image de chaque microfiche, selon le cas: le symbole $\rightarrow$ signifie "A SUIVRE", le symbole $\nabla$ signifie "FIN".

Les cartes, planches, tableaux, etc., peuvent être filmés à des taux de réduction différents. Lorsque le document est trop grand pour être reproduit en un seul cliche, il est filmé à pertir de l'angle supérieur gauche, de gauche à droite, et de haut en bes, en prenant le nombre d'images nécessaire. Les diagrammes suivants illustrent la methode.

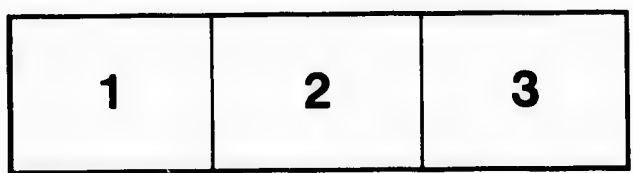

\begin{tabular}{|l|l|l|}
\hline 1 & 2 & 3 \\
\hline 4 & 5 & 6 \\
\hline
\end{tabular}

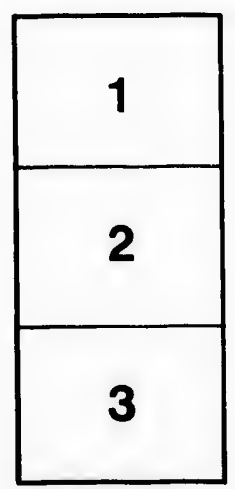




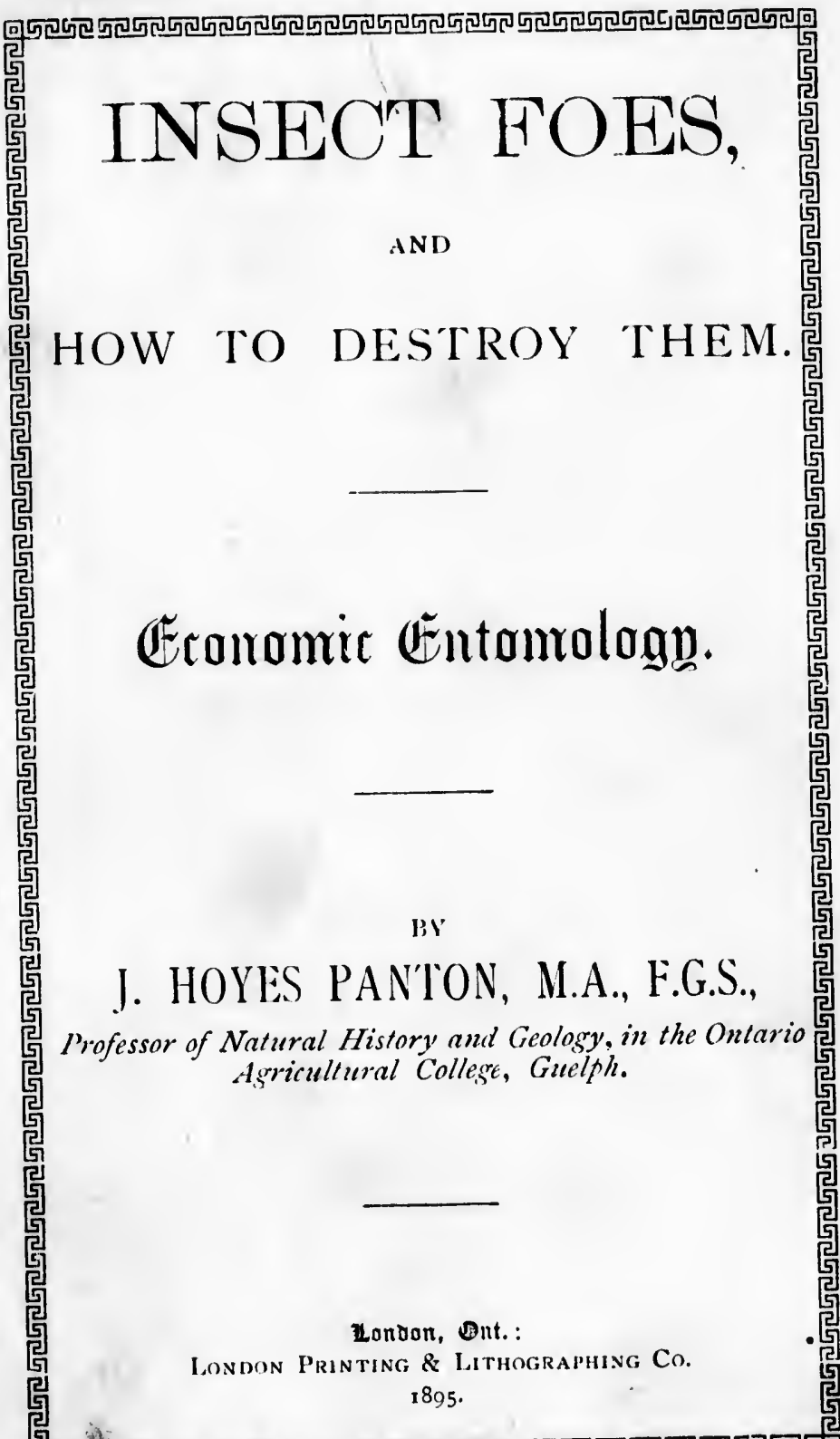

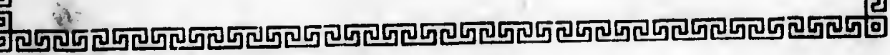




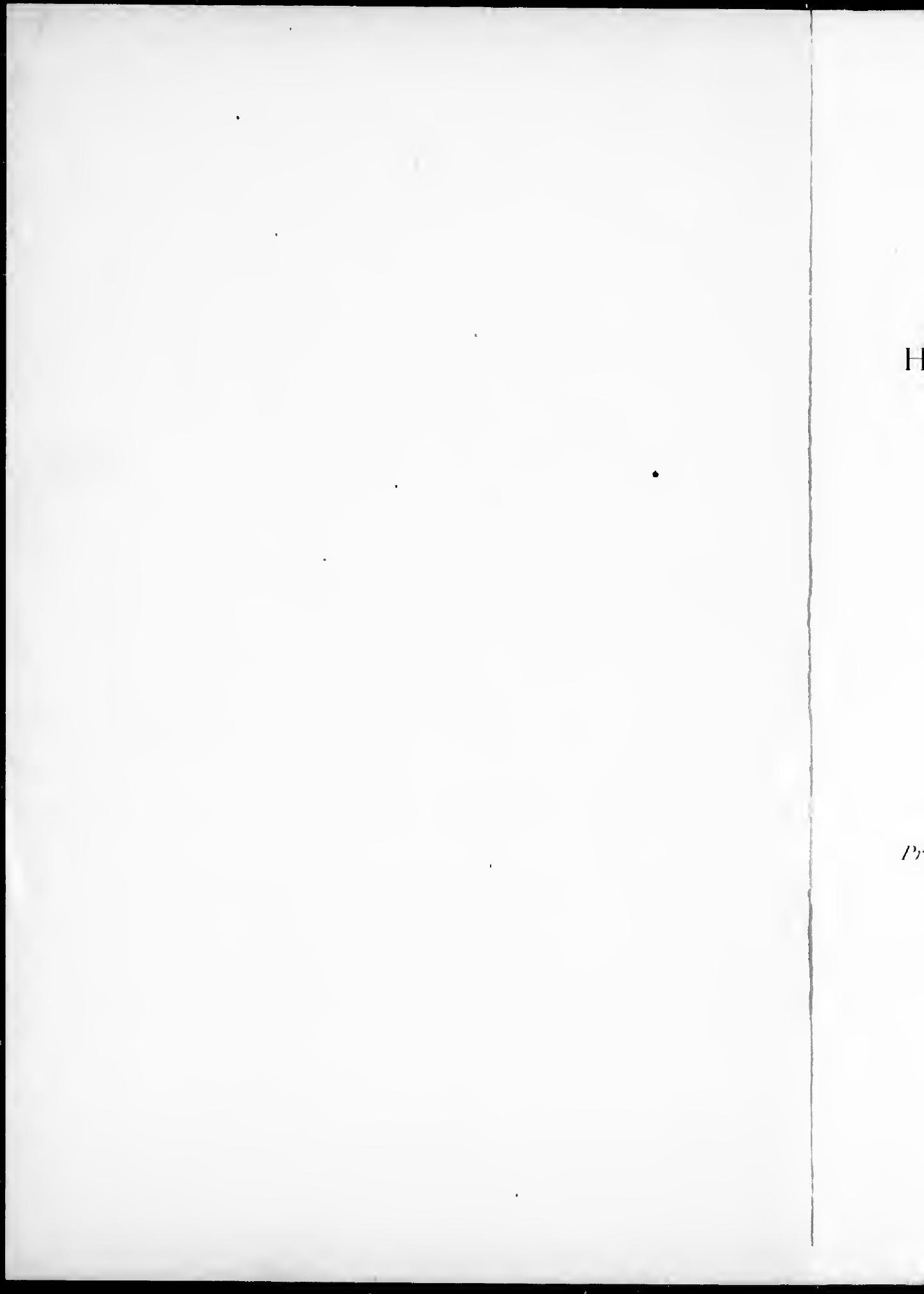




\title{
INSECT FOES,
}

ANI)

HOW TO DESTROY THEM.

Eronomit Ëntomrologn.

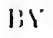 \\ j. HOLLS PANTON, NA., FGS \\ Irefessom of Netural History and Geolngy, in the Onturio \\ Inticultural Colleste, Giteith.
}

Zundort, Dnt.:

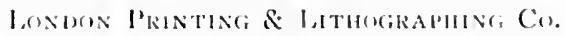

1895. 
Se951

P3 


\section{PREFACE.}

This book has been written for the purpose of supplying Teachers in rural schools with facts relating to Economic Entomology.

'The writer believes that if the last hour on Friday were spent in giving a talk upon this subject, during a portion of the summer term, and the pupils encouraged to make a coliection of the beneficial and injurious insects in the section, they would very soon have a fair knowledge of the subject, and the school possess a good collection of insects. The first edition of his Geology, written a year ago, to furnish facts bearing upon the composition, origin and formation of the rocks in Ontario, being almost all sold, has encouraged him to try and also make simple and attractive the teachings of Entomology-a study of much importance to the gardener, the fruit-grower, and the farmer.

If agricultural science were taught in our rural schools, one hour a week, as recom- 
mended by the writer, there is no doubt a good knowledge would be obtained of science, as it is related to the work upon the farm, and we would soon have in our rural districts many observers of nature; many eager and intelligent readers of agricultural science; a stronger attachment to the farm, where nature is so largely revealed; and in every school'a museum illustrating the geology, botany and entomology of the district.

\section{J. Hoyes Panton.}

\footnotetext{
(iUki.l'H,

March 11, 895.
} 


\section{INDEX.}

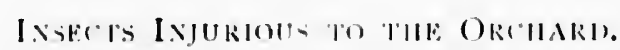

Affictin," the stpli-

l'ages.

Borers

Cecropian Moth

$40-42$

Tent Caterpillar

- 49.50

Tussock Moth

51,52

Corlling . Ioth

52

Cankerworm

53,54

lall Webworm

$-55,5^{6}$

liellow-necked Caterpillar - - - - $6 \mathbf{I}$

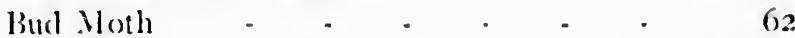

Plant-lice - - - - - - $\quad-65,66$

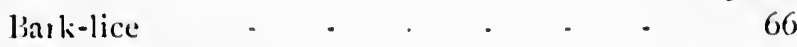

.lfertinis the Pinm-

Curculio - - - - - - $\quad$ - $\quad 34-36$

I'lum Sphinx - - - - - - 44

Telea Moth - - - $\quad$ - $\quad$ - $\quad$ - $\quad$ - 50

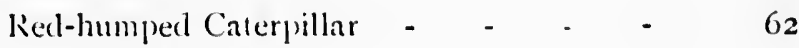

Plum Scale - - - - - - - - 71

Affeting the Peath and Piar-

Peach Borer - - - - - - $\quad$ - 59,60

P'ear-tree Slug - - - - - - $\quad-27,28$

l'ear-tree P'sylla $\quad-\quad-\quad-\quad-\quad-\quad 70$ Iffiting the Cherry-

May Beetle - - - - - - - 38

Io Noth - - - - - - - - 48

l'romethea Moth - - - - - - 48 
Ixsects INJURIOUS TO THE GiARIN. Affectingr Celery', Tomato, elc. -

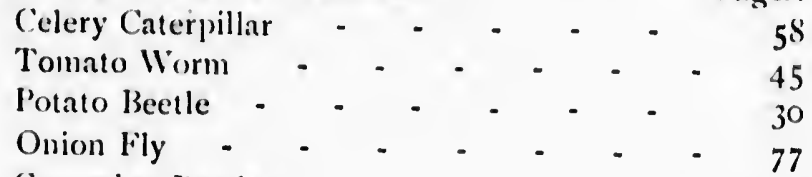

Cucumber Beetle - - - - - - 31,32

Siquash Bug - - - - - - - . 64

Currant Worm - $\quad$ - $\quad$ - $\quad$ - $\quad 20$ Affecting the Cabliage-

Cutworms - - - - - - - 46.48

Calbage Worm $\quad$ - $\quad$ - $\quad$ - $\quad$ - $\quad$ - 54

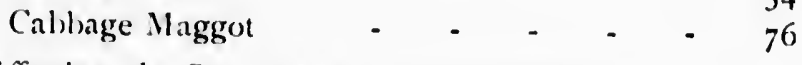

Iffedings the Stratiberry and liast berry-

White (irul) - - - - - - 38

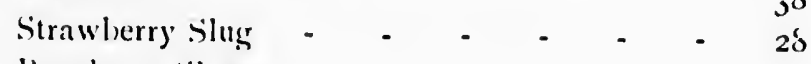

Rasplerry Slug _ - - $\quad$ - $\quad$ - $\quad 28$

Rasplberry Borer - - - - _ - 60

Tree Crickęt - $\quad$ - $\quad$ - $\quad$ - $\quad$ - 83

Iffecting the cirnpe-

(impe lieetle

Rose Bug .

Coldsmith beetle - $-39,40$

Peliclnota Beetle $-{ }^{-}-{ }^{-}-43$

Grape Sphinx $-{ }^{-} \cdot 4^{-}$

Vellow IVoolly

Vellow Woolly Bear - - _ _ - $\quad 6$ - 6 I

Insects INIURIOUS TO THE FIELL.

White Girul - - - - - - 38

Turnip Bectle - $\quad$ - $\quad . \quad-\quad \quad-\quad-\quad 29,3^{0}$

P'en Weevil - $\quad$ - $\quad$ - $\quad$ - $\quad$ - $\quad$ - 33

Wireworms $\quad-\quad-\quad-\quad .36,3^{8}$ 
Insfers Inguklous ro lat likis. (Continued.)

P'ages.

Clover Borer - - - - - - - 42

Cirain Weevil - $\quad$ - $\quad$ - $\quad$ - 43

Army Worm - - - - • - $55^{6}$

Wheat Midge - $\quad$ - $\quad$ - $\quad$ - $\quad 72$

Clover Midge - $\quad$ - $\quad$ - $\quad$ - $\quad$ - $\quad$ - 74

Hessian Fly - - - - - - - 7 i, 74

Crane-Fly - - - - - - $\quad-79$, So

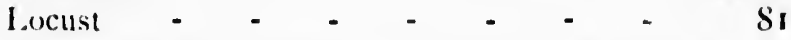

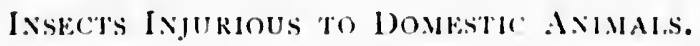

Cittle, eti. -

lice - - - . - - - 67.68, 4

Bots, Ticks - $\quad$ - $\quad$ - $\quad$ - $\quad$ - ys.So

Horn.lily - - - - - - - 7; 


\section{CHAP'TER I.}

The Impgrtance of Economic Entomology.

'The study of insects in relation to man has of late years commanded much attention, and is usually referred to as Economic Entomology. While there are some insects beneficial to man, there are many injurious. Some destroy his food, some injure his clothing, and others attack the animals that are of use to him.

Nearly 100 species have been found preying upon his grain and forage crops; upwards of 40 upon his vegetables; 50 upon the grape; 75 upon the apple.

The pine has 125 species as enemies; the oak, 300 ; the elm, 80 ; the hickory, 170 ; the maple, 75 ; the beech, 150 ; while the unfortunate willow battles against 400 insect foes.

The following statistics show what an immense loss is sustained by man from insects :1 854 - The United States lost \$15,000,000 by the wheat midge.

I 857 -Canadit lost $\$ 8,000,000$ by the wheat midge.

1864 -The United States lost $\$ 73,000,000$ by the chinch-bug. 
$1870-$ New York State lost $\$ 5,000$, coo by the cabbage worm.

1873-The Southern States lost \$25,000,000 by the cotton worm.

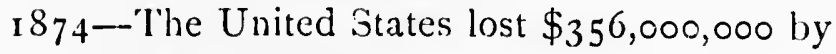
the grasshopper.

I 884 --Canada lost $\$ 500,000$ by the clover nidge.

The average loss of the United States from insects during 1884 is calculated to have been $\$ 400,000,000$, and for IS9I, \$300,000,000. With such figures before us, in most cases under the mark, we must conclude that the study of a subject that will enable us to lessen this loss is of great importance.

Many of our injurious insects have been inported, and with us seem to become more destructive than in the country from which they came. This may be accounted for by their having fewer enemies to prey upon them, such as jarasitic insects and birds, and also that wider areas are found here for their feeding grounds. Before giving a description of the insects that are injurious to the products of the garden, orchard and field, let us consider what the general nature of an insect is, and the groups into which they have been classified. 


\section{CHAPTER II.}

\section{'The Parts of an Insect.}

An insect may be described as having three well-marked divisions: head, thorax, and abdomen; one pair of antenna (feelers), three pairs of legs, usually two pairs of wings; respiration by means of tube-like structures (trachece), simple and compound eyes and jointed limbs. Most insects undergo metamorphosis - that is, pass through a series of well-marked changes in their development from the egg to the adult condition.

'The following shows the place of the insect in the animal kingdom :-

Kingdom, Sub-kingdom, Class, Sub-class, Animal. Arthropoda. Insecta. Hexapoda.

The Arthropoda embraces two classes: Crustacea, represented by crabs, lobsters, etc., and Insecti. The Insecta contains three subclasses: Myriapoda, centipedes and millepedes; Arachnida, spiders and scorpions; Liexapoda. the true insects.

From this it will be observed that spiders are not true insects; they have four pairs of legs 
and other characters which place them in another division.

Among insects we find two typical mouths: the masticatory or biting, characteristic of beetles and the larve of many insects; and the suctorial or sucking, represented in butterflies and plant-lice. A knowledge of these facts becomes of importance in the application of insecticides. Insects with masticatory mouths can be readily poisoned by applying some poison, such as Paris green, to their food; but those possessing a suctorial mouth must be treated with a substance that kills by contact and not by being introduced into the digestive system. Such insecticides as Kerosene Emision and Pyrethrum powder are suitable for this mode of treatment. Thus, by knowing the nature of the mouths, we are able to suggest what substance is likely to be effective in destroying insects.

Head.-The head of an insect consists of several parts, the most important of which are those that enter into the composition of the mouth, viz.: labrum, or upper lip; mandibles, or upper jaws; maxille, or lower jaws; and labium, or under lip. In a masticatory mouth the mandibles and maxilla are highly developed, 
while in a suctorial the maxillit largely constitute the sucking apparatus.

Upon the head are borne the antennce or feelers, and the eyes.

Thorax. - The thorax consists of three segments-usually distinct, but in some united. The first (prothorax) has a pair of legs; the second (mesothorax), a pair of legs and a pair of wings; the third (metathorax), also a pair of legs and, in most cases, a pair of wings.

The Diptera (flies, etc.) have only one pair of wings. In the absence of a second pair, we sometimes find them represented by the socalled "balancers," structures resembling knobbed antennæ. 'The wings consist of two layers, between which are the structures known as veins or nerves, and certain vessels (trachere) connected with respiration. In the beetles, we find the first pair of wings much thickened. The legs in insects consist of 6 to 9 segments, modified according to the nature and habit of the insect.

Abdomen.-This contains o to I s segments; the last in some females is modified into an apparatus (ovipositor) used in depositing eggs.

The digestive system in insects is quite complicated, possessing several well-defined organs, 
such as gizzard, stomach, small and lurge intestines.

The cirulatory system varies much; it has no regular and defunite course, as in higher animals.

'The heart is a long, contractile vessel, situated near the back, and consists of numerous cavities (usualiy eight) opening into one another by valves; the blood moves in the direction of the head, and passes from the heart to different parts of the body, into small spaces in the tissues, from which it is returned to the last cavicy of the heart, and proceeds towards the head, and thus the circulation is kept $u_{i j}$. The blood is usually colorless or tinged with green.

'The respiratory system consists of a series of tubes (tracliece) in the body, and from these branches rise, so that the air is conveyed to different parts. 'These tubes are brought into relation with the outside air by small openings (spiracles), usulily situated along the sides: two in each segment, one on each side.

In some aquatic insects the spiracles open under the wings, while in maggots they are at the posterior end of the body. In all likelihood the wings assist in respiration, for we find 
trachea placed along some of the veins between the membranes of the wings.

The nervous system consists of a chain of nerve centres (ganglia) located on the lower side of each segment and united by a series of double cords. With this system the organs of taste, smell, touch, sight and hearing are asso. ciated.

The sense of smell is connected with the antenne, in which nerves are found and certain pits known to assist it.

The sense of taste seems to be comnected with the under part of the mouth.

'T he sense of touch is associated with the hairs upon the antenna, palpi, legs, and even the body.

The sense of sight is located in the eyes, two kinds of which are found in many insects: simple and compound. The simple eyes are usually three in number ; the compound, two, made up of many divisions called facets. Some buttenflies have 30,000 facets in one eye.

'The sense of hearing in grasshoppers is located just behind the first abdominal spiracle; in the locusts it is located in the fore legs. Grasshoppers produce sound by rubbing their legs over the wings; locusis rub the wings upon each other. 
The muscular system is internal, being located within the limbs, while in higher animals it is external.

Most insects lay eggs, but some produce living young, and some pupce.

The development of an insect is represented by four stages-egrr, larva, pupa: imago.

The larva (larva, a mask) is frequently without external organs and has a biting mouth; hence, is a great feeder and usually very destructive to vegetation. The larval condition continues from two to six weeks in most; but there are some in which it is more than a year, e. $g$, the wire-worm, white grub, and some "borers."

Pupa (pupa, a doll). 'This is generally a resting condition, which, in summer, usually last; but a short time (about two weeks); but if entered in autumn, continues till the next spring. The term chrysalis (chrysos, gold) is often applied to this stage in butterflies, because in some it is dotted with golden spots. In most moths a cocoon is woven around the pupa. Nymph is applied to the young of such as do not undergo complete metamorphosis in development; in such the young are much the same in appearance as the adult, but smaller, and usually wingless; e.gr., grasshoppers, bugs, etc. 
Imago (imago, an image). 'This term is applied to the perfect insect, which is often harmless, as far as feeding upon vegetation is concerned.

The following names show some of the common terms applied to these stages in some orders of insects :Larva, . . . . . . . . Pupa, . . . . Imago. Borer, grub, . ..... " . . . . Beetle. Maggot,........ " $\ldots$....Fly. Caterpillar or worm, Cocoon,.... Moth.

" " Chrysalis,... Buttertly. Nymph,......... Nymph, ... Grasshopper. 


\section{CHAPTER III. \\ Ciassification of Insects.}

For convenience in study, insects are divided into seven orders, the classification being based upon the nature of the wings. 'The number and arrangement of the veins in insects is of great importance in grouping them into families and orders.

I. Hymenoptera (hymen, a membrane; pteron, a wing).

'The insects in this order undergo complete metamorphosis; the mouth is partly masticatory and partly suctorial; the wings are membraneous. In this group we find the architects, manufacturers, and guards of the insect world, e.gr., bees, wasps, ants, saw-flies, and ichneumons. Some have stings as organs of defence (bees), some pierce with an ovipositor other insects (ichnemmons), and some use the ovipositor for piercing leaves, so as to secure a proper place for their eggs (saw-tlies).

2. Coleoptera (koleos, a sheath; pteron, a wing).

This order is a very large one. The metamorphosis is complete ; the first pair of wings is 
much thickened, while the second is filmy, and all have a masticatory mouth, e.g., beetles.

3. Diptera (dis, twice; ptcron, a wing).

In this order there is only one patir of wings, and complete metamorphosis occurs.

The mouth is suctorial. As many in the larval condition (maggots) feed $u_{i}$ )on decaying substances, they have been called the scavengers of nature.

'This order includes flies, gnats, fleas, and mosquitoes.

4. Lepidoptera (lepis, a scale; pteron, a wing).

The insects in this group have suctorial mouths, wings covered with scales, and uncergo complete metamorphosis, the larva, pupa and imago being very marked. 'The moths and butterflies belong to this group, which is one of the largest among insects. Moths usually have feathered antennie, wings horizontal during rest, pupa generally covered with a cocoon oval in outline, and are most active at night, while butterflies have knobbed antemna, wings erect during rest, pupa naker and angular, and are most active during the day. The larve in this order are termed caterpillars. 
5. Neuroptera (neuron, a nerve ; ftroll, a wing).

'This division includes a great variety of forms, which by some are considered sufficiently inarked to be placed in separate orders. So widely different are some of the forms here, that this division has been broken up into eight distinct orders. In some metamorphosis is complete, while in others it is incomplete (that is, the different stages in development are not wellmarked).

The wings are very full of veins; more so than among the Hymenoptera. 'The mouth is masticatory.

Dragon-flies, May-flies, white ants, lacewinged flies, and bird-lice belong to this division.

6. Hemiptera (hcmi, half; pteron, a wing).

Here metamorphosis is only partial, the larva and pupa resembling the imago, but wingless and smaller; the mouth is suctorial. 'Ihe' lower part of the front wings in many is much more membraneous than the upper. 'This order embraces plant-lice, true lice, and bugs.

7. Orthoptera (orthos, straight; pteron, a wing).

The first pair of wings are stright, narrow, and 
thickened, while the second, folded like a fin, are membranous ; metamorphosis is partial, and mouth masticatory. 'The grasshoppers, locusts, crickets and cockroaches belong to this group). The orders 1, 2, 4 have always remained the same in classifications adopted from time to time; 3, 6, 7 have been modified very little; but 5 has been much divided. I atterly it has been, as already remarked, divided into eight orders, so that in the most recent classifications we find 16 orders instead of seven, and some entomologisl favor a classification containing I 9 orders.

The following are popular methods of classifying insects :--

(a) According to their usefulness.

Beneficial.-'The bee (honey); silkworm (silk); cochineal (dye); ichneumon (feeds on injurious insects).

Noxious. - Those affecting the products of the field (midges, etc.); the garden (cut. worms, etc.); the orchard (borers, etc.).

Neutral.-Such as are neither injurious nor beneficial.

(b) According to their mode of injury.

External feeders, such as caterpillars, etc. Internal " " borers, etc. 
Underground feeders, such as cut-worms.

Granary pests, such as pea-weevil, etc.

Household pests, such as flies, etc.

Parasites upon domestic animals, lice, etc. 


\section{CHAPTER IV.}

Benelicial, Birds and Insects.

In the study of Economic Entomology, it is essential that we know something about insectivorous birds, especially such as feed upon injurious insects, as well as to have a knowledge of beneficial and injurious insects.

Many investigations have been carried on to learn what insectivorous birds are useful in assisting man to keep in check his insect foes.

Thousands of birds have been shot, and the contents of their stomachs examined, so as to ascertain with accuracy if the insects eaten were injurious. In some cases as many beneficial insects were devoured as those harmful. The result of careful examination into the subject has been to consider the birds named in the following list as benefactors to the farmer, the fruit grower, and the gardener, and should, as far as possible, be protected and permitted to increase in number:-

King bird, pewee, night-hawk, swallow, whippoor-will, American redstart, yellow-billed cuckoo, blue bird, white-bellied nuthatch, redheaded woodpecker, high-holder, hairy wood- 
pecker, downy woodpecker, golden warbler, red-eyed greenlet, yellow-throated greenlet, Wilson's thrush, brown thrush, cat bird, redwinged blackbird, crow blackbird, oriole, meadow lark, indigo bird, song sparrow, grass finch, chipping sparrow, chewink, purple finch, snow-bird, American goldfinch, horned lark, wren, chickadee, golden-crowned kinglet, rubycrowned kinglel, and American creeper. Among the nost beneficial insects we find the following in the different orders :

Order Diptera.-Syrphus fly, Tachina fly.

O. Coleoptera.-Cicindela (tiger beetles), Calosoma, Harpalus (ground beetles), Coccinella (lady-birds). bugs)

O. Hemiptera-Reduvius, Arma (soldier

O.Neuroptera.-Chrysopa (lace-winged flies).

O. Hymenoptera.-Vespa (wasps), Chrysis (cuckoo flies), Ichueumons.

The above insects are of great importance in keeping the injurious insects upon which they prey in check. 'The ichneumons are most valuable in this respect. 'They are very numerous, and prey on many injurious insects, by depositing eggs in the larval forms. These eggs give rise to larval ichneumons that feed upon their 
host, which finally dies. About this time the ichneumons are developed, and escape as perfect insects. The lady-birds are destroyers of plant-lice; ground beetles prey on the potato beetle and several caterpillars, and the tiger beetles are great devourers of several species of insects. 


\section{CHAPTER V.}

Methods Adopted to Destroy Insects.

Among the most importint methods followed to overcome injurious insects are the following:

I. Use of insecticides, such as Paris green and kerosene emulsion.

2. Poisonous gas, generated in tents placed over shrubs and trees affected by scale insects, etc.

3. Entrapping the insects, such as codling moth and cankerworm.

4. Using barriers to check the progress of injurious forms, such as chinch-bug, armyworm, etc.

5. Protection of insectivorous birds and beneficial insects.

6. Using parasites, which cause insects to become diseased, such as certain bacteria that are scatterd among those to be destroyed.

7. Agricultural remedies, slich as rotation of crops, varying the time of sowing, using good seed, using fertilizers, cleanliness in fields, drainage, fall-ploughing, and summer-fallowing.

In the study of Economic Entomology, it is of great importance 10 make a collection. Most 
collectors are satisfied to secure specimens of the imago; but if it is desired to study them from an economic standpoint, specimens of the different stages in an insect's life should be secured. If injurious forms are to be considered, it is of more importance to know the larva than the imago. 'The writer would, therefore, recommend teachers who are interesting their pupils in entomology, to encourage them to collect eggs, larva, pupa, and imago of the injurious forms. About sixty species would embrace most of our common insect enemies. Such a collection would be very instructive to the pupils, by showing the different stages in insect life. With these might be associated the most beneficial insects, the whole forming a very complete series of specimens, suitable for obtaining a practical knowledge of insects.

For information regarding how to collect, kill and mount insects, we would recommend "Entomology for Beginners," by A. S. Packard, and published by Henry Holt \& Co., New York. Square bottles, with neck turned up like the letter $J$, are very convenient for holding larve. Shaped in this way, there is no fear of the preserving-fluid getting out. IVe find many larva are readily kept in alcohol, diluted with about 
one-third water. 'The above bottles (size, 1/2 oz.) can be obtained from Whitall, Tatum \& Co., 4 I Broad street, Boston, at 40 cents a dozen. Pins and other entomological supplies can be obtained from W. E. Saunders, London, Ont.

Insecticides are compounds or mixtures used to destroy insects injurious to vegetation.

Paris Green.-(Arsenite of copper, containing 50-60 per cent. of arsenic.) 'This is applied dry or in solution. In the dry form, it should be mixed with 50 to 100 parts of plaster, woodashes, flour, or air-slacked lime, and dusted upon the affected plants. The form in solution is usually I lb. of Paris green to 200 gals. of water; but if the foliage is tender, 250 to 300 gals. of water may be used. This is the usual strength applied upon the plum and peach. As the green powder does not dissolve, it requires to be kept thoroughly mixed by constant stirring. One pound of lime to every 100 gallons will prevent injury to the foliage. The Paris green should be first made into a thin paste, in a small quantity of water, and then added to the full amount of water.

London Purpie.-This is an arsenite of lime, obtained as a by-product in manufacturing dyes. It is largely used instead of Paris green; but 
being more soluble in water, it is not apt to injure the foliage, and, besides, its composition varies considerably, so that when used it is not likely to give as uniform results as Paris green. These arsenites are excellent against all leafeating insects.

Kerosene Emulsion. - This is a mixture of coal oil and water.

- (1) Riley-Hubbard Emulsion.-Consists of half-pound of hard soap in one gallon of water. Boil till dissolved, and then add two gallons of coal oil, and mix thoroughly for about five minutes. When properly mixed, it will adhere to glass without oiliness. This can be done by forcing it through the nozzle of a force-pump repeatedly until the mixture appears complete. It will then form a creamy mass, which thickens into a jelly-like substance on conling. In using, dilute with nine parts of soit water. This form is very commonly used and is easily prepared. If the foliage is very tender, the emulsion must be more dilute, i 5-20 parts water.

Whale-oil soap is better than the common hard soap, especially if the emulsion is to be kept for some time. Soft soap may be used instead of hard, using one quart. Where the water is very hard, sour milk may be taken ; in 
that case you require only to mix the coal oil (two gallons) and milk (one gallon) to get the emulsion, the soap not being required. This emulsion is liable to spoil if kept long. Kerosene emulsion is a most successful remedy for plant-lice and scale insects.

Hellebore.-Obtained from the powdered roots of a plant (Veratrum album). May be applied dry or as a liquid. One ounce to three . gallons of water. Excellent against currant worm and cherry slug.

Pyrethrum. - Made from the powdered flowers of the genus pyrethrum, a plant of the sunflower family. It should be fresh, anḑ hence should be kept in closed vessels. Used in dry form : one part pyrethrum, five to eight parts flour; or liquid: one ounce in three gallons water. A good remedy for cabbage worm.

Carbolic Acid Emmlsion.-One part carbolic acid to five or seven parts of a solution consisting of one quart soft soap, or one pound hard, in two gallons water. 'lhis, applied to affected trees, destroy's bark-lice and the borers. It should be well rubbed upon the parts altacked.

Carbolized Plaster.-A mixture of carbolic acid and land-plaster: one pint of the former 
and fifty pounds of the latter. A remedy against flea-beetles.

Tobacco.-The refuse from cigar manufactories answers the purpose. Take one pound of tobacco to three gallons of water, boil thirty minutes. Add water to make the three gallons, and it is ready for use. 'This is excellent to destroy plant-lice.

Alkaline Wash.--A strong solution of washing sorla, mixed with soft soap until about as thick as paint. Applied to the trunk of trees, destroys the borers, and gives a healthy, vigorous tone to the tree.

Carbon Bisulphide.--'This colorless liquid is a most effectual remedy to get rid of insects in granaries, but great care requires to be taken, as it is very inflammable and explosive, and may lead to serious results if any fire is brought near ; even a cigar or pipe, used where the vapor is being evolved, may prove disastrous. It readily volatilizes; the vapor is heavier than air, and is deadly to insect life. In using it, the liquid may be placed in a small shallow vessel and put on the top of the grain, in bins or barrels. 'These are covered so as to keep in the vapor, which sinks down through the grain, destroying insect life wherever it comes in con- 
tact with it. After the operation is over, the grain will lose all odor in a short time, if exposed to the air. Some prefer taking a wad of cotton or tow, saturating it with the liquid, then plunging it into the middle of the bin and leaving it. 'I'wo or three bunches, thus placed among the grain, will soon kili all such pests as are found in it. One ounce is about sufficient for two bushels of grain.

In giving the remedies referred to in the following pages, wherever Paris green is mentioned, and no propctions named, it is understood to be the common formula: One pound of Paris green to 200 gallons of water. This also is the case where hellebore and pyrethrum are recommended. It is considered unnecessary to repeat the remark in each case, that where the vigor of plants can be increased by the use of fertilizers, it is well to use them. A strong, healthy plant is always in a much better condition to withstand the attack of insects than a weakly one. Thorough cultivation and cleanliness are always to be followed as far as possible; a want of the latter in many cases leaves sheltering places for injurious insects, which are enabled to winter favorably and become a trouble the following season. Whereas, 
if weeds, etc., were not allowed to grow, no hiding places would be furnised, and many would perish from exposure.

In nearly all cases, Paris green is an effectual remedy against insects that feed by chewing; but in cases where its application might effect the fruit, some other remedy must be adopted. Kerosene emulsion is also a most successful general remedy when applied upon insects that feed by sucking the juices of plants, such as plant.lice. IVe thus have two insecticides which cover almost every case, and are no longer required to learn a different remedy for each pest, as was necessary not many years ago. The application of insecticides has also been made comparatively easy by the invention of spraying machines, which are rapidly becoming an important factor in gardening and fruit growing. 


\section{CHAPTER VI.}

InJURIOUS INSECl'S IN IHE: ORINR HYMENOPTERA.

There are not many injurious insects in this order; the principal being what are known as saw-flies, so-called beciuse some of them are supplied with an ovipositor, with which they can bore into leaves and deposit their eggs.

\section{Currant Worm (Nematus ribesii).}

This insect is very troublesome upon currant and gooseberry bushes. It lays its egrrs early in the spring, on the under side of the leaves, in rows along the veins. 'These hatch in about ten days, and the young worms appear. The larva, when full-grown, is about three-quarters of an inch in length, of a greenish color, spotted with dark spots, and has many legs. It spins a brown cocoon, of paper-like texture, which is found sometimes on the ground among the dried leaves, or on the bush, attached to the stems or leaves. 'This represents the pupa condition.

'The imaso appears' in aboul two weeks after the pupa stige has been entered. The male is much smaller than the female, the body 
black, with some yellow spots above, while in the female the body is mostly yellow. Both have four membranous wings. A second brood is of common occurrence.

$$
\text { REMIIMLS. }
$$

I. Hellebore, one ounce in three grallons of water. It mavalso be applied as a dry powder, mixing it with three or four parts flour.

2. Paris green for the first brood, but care must be taken not to contimue this if the fruit ikely to be affected.

\section{ar-Tree Slug ( Lrriocampa ierasi).}

'The esors are laid about June, in semi-circular incisions made through the skin of the leaf by the insect's ovipositor.

'The larow is about one-half inch in length, and is thicker towards the head, of a some. what greenish-black color, and slimy. It has many legs, and gives off a disgusting odor. The pupa is in the ground, two or three inches below the surface, in an oval cavity. This condition lasts two wecks.

The imagro is a small, four-winged black fly, about one-fifth of an inch long. 'There are usuaily two broods. 'This insect may be found attackng the pear, plum, and cherry. 
REMEDIES.

I. Spraying with Paris green, hellebore, or pyrethrum, in the common proportions.

2. Fresh-slacked lime, dusted upon the trees. Raspberpy Slug (Selandria rubi).

The eggs of this saw.fly are also deposited beneath the skin of the leaf. The larva is dark greenish, covered with transverse rows of white spines, and about half an inch long. The pupa is in the ground.

The imago is a small, four-winged black fly, which lays its eggs in the leaves of the raspberry. REMEDY.

I. Spray hellebore, one ounce to four gallons of water.

\section{Strawberpy Slug (Empliytus maculatus).}

The eggs are deposited in the leaf or stem. The larva is pale green, about three-fourths of an inch long. It enters the ground and becomes a $p u p a$, from which the imago emerges as a small, black, four-winged fly, with two rows of distinct white spots on the body.

\section{REMEDIES.}

I. Pyrethrum poivder,dusted upon the plants.

2. Paris green, if another brood appears after the fruit is gathered. 


\section{CHAPTER VII.}

INJURIOUS INSECTS IN THE ORDER Coleoptera.

This is one of the largest orders among insects, and in it are many injurious to vegetation. The stages in development are wellmarked.

\section{Turnip Beetle (Phyllotreta zittata).}

The eggs are laid upon the roots of the turnip. The larva is about one-fourth inch long, and feeds, to some extent, upon the roots. It passes the pupa stage in the ground.

The imago is a small, shinirg black beetle, with a yellowish, wavy stripe on each wing. cover, and is only about one-tenth inch long. It feeds upon the leaves, not only of the turnip, but, also, of the cabbage and radish; sometimes doing much damage. It passes the winter beneath clods of earth, etc., and in spring attacks plants of the cruciferce order. It cannot do much harm after the fourth leaf comes upon the turnips. Several broods may appear in the season. 
REMEDIES.

I. Paris green, mixed with twenty-fice parts flour, or 50 plaster, by weight, dusted on the plants while the dew is on.

2. Some claim that if the seed is soaked in coal oil, and dried with lime, it will be successful in keeping the beetle away.

3. Coal oil mixed with sand and scattered on the plants.

4. 'Tobacco powder, dusted on the plants, gives good results; or, Tobacco solution, one pound to two gallons water.

Potato Beetle (Doryphora decem-lineata).

The deep orange-colored egrrs of this insect are laid in clusters $(30-60)$ on the under side of the leaves, and hatch in a week. The larra is a voracious feeder; when fully developed, it passes into the ground, where the pupa stage cominues for ten days.

'The imagro (about half an inch long, and oval in outline) has five black stripes on each wingcover, the gencral color being a yellowishbrown. One female will lay as many as seven hundred eggs, while one pair in a season may be the parents of $38,000,000$. When this insect is disturbed it drops from the leaf. Many parasites prey upon the potato beetle, yet it 
ECONOMIC ENTOMOIOGY.

survives against all its foes. Its native home is on the eastern slope of the Rocky Mountains. In 1874 it reached the Atlantic States. This pest is too well-known to require further description.

REMEDIES.

1. Paris green, with fifty times its weight of flour, or one hundred parts land-plaster, dusted on the plants. Paris green is generally applied in solution, using about one pound to one hundred gallons of water.

2. Shaking the vines and collecting the dropping beetles.

\section{Cucumber Beetle (Diabrotica vittata).}

The eggrs are deposited in the soil about the stems of the plants, and as soon as hatched the larva fecds upon the roots. It is about half an inch long, with three pairs of legs in front and a leg-like structure on the last segment. It passes the pupa condition in the soil. The imago is about one-fourth of an inch long, and is somewhat yellow, with black stripes on its back. It feeds upon the leaves and stems of plants attacked, and passes the winter, as a beetle, under any rubbish which will afford shelter. It feeds upon the squash and melon, as well as upon the cucumber, and is a very difficult insect to overcome. 
REMEDIES.

I. About the only successful remedy is to cover the plants with boxes, having fine gauze netting for the bottoms, or to make frames of hoops covered with netting, so as to form a kind of dome over the plants.

2. A liberal use of tobacco powder has given good results.

3. Some report success frum sprinkling soot. Grape-Vine Beetle (Haltica chalybea).

The eggs are deposited on the under side of the leaves. The larva is about one-third of an inch long, brownish, with several black dots on the body. The pupa condition is passed in the ground, and continues for about three weeks.

The imago is a smill, polished beetie, about one-fifth of an inch long It passes the winter in sheltered spots, under leaves, or around the roots, and is very destructive in spring to the young buds, and afterwards, in the larval condition, to the leaves.

REMEDIES.

I. Paris green, three ounces to fifty gallons water.

2. Dust pyrethrum powder upon the vines attacked.

3. Jarring the vines in the morning and collecting the beetles. 


\section{Pea Weevil (Bruchus pisi).}

The egros are laid on the pods, as soon as they are formed and the seeds set. The larva, as soon as hatched, bores into the pod, reaches the peas and works into them, eating much of the substance, but leaving the germ untouched. The pupa is in the pea, where it can readily be seen. The imago emerges in spring, as a small beetle, about one-fifth of an inch long, dark colored; head well-bent under the body, which is oval in outline; short antenne, and the wingcovers shorter than the body. Sometimes the imago appears in autumn, and passes the winter in some sheltered place.

\section{REMEDIES.}

I. Sow unaffected peas. Seed containing bugs will germinate, but do not produce vigorous planis.

2. Seed lept over for a year in closed vessels wiil be free cf bugs, as they would be dead hy that inre.

3. Heat the peas to $1+5^{\circ}$ Fahr., as soon as gathered.

4. Place the grain in an air-tight vessel; pour some carbon bisulphide in a saucer on top, and cover the whole up for forty-eight hours. The heavy vapor will sink among the 
peas and destroy the bugs or any insects in or among the grain. One ounce is said to be sufficient for 100 pounds of grain. As this compound is very inflammable and volatile, great care should be taken not to bring any light near it. Lately a case came under the writer's notice, where a person hac used this substance by simply placing it in an open vessel and setting it upon the grain, without covering the whole, so as to keep the vapor in, and, of course, much of its effects were lost, while at the same time this inflammable vapor was to some extent escaping in the groury and barn, where it might have been ignited from a pipe, or match, and led to serious $x$ ulti. If the peas treated are exposed to the air a short time the offensive odor will pass away.

\section{Plum Curculio (Conotrachelus nenuphar).}

The egrr of this insect is deposited in the plum.

The larva burrows in the fruit, where it matures in three or four weeks. That affected soon falls to the ground, and the larva leave. the plums, pass into the ground, and become pupe, in which condition they remain for about six weeks. 
The imago is a small grayish-brown beetle, one-fifth of an inch long, with a black hump on the middle of each wing.case. It has a curved snout and a stout body.

The beetles conceal themselves during the winter, in sheltered spots, and appear in the spring about the time the trees are in bloom; but, some pass the winter as fupce. 'This insect does not confine itself to plums, but is found upon the cherry, peach, and even apple. A single female may lay as many as two hundred eggs.

In laying her egg, she first makes a small hole in the plum; into this the egg is placed; she then cuts the crescent marking around it; this is supposed to be done for the purpose of checking the growth of the cells near the egg, and thus prevent its being injured.

Plums marked in this way are said to be "stung"-a rather poor term, as the mark is made with the insect's curved snout.

REMEDIES.

r. Jarring the trees, morning and evening. Where this is done, very many beetles drop from the tree, and may be collected upon a sheet placed below. Many plum growers prefer this to any other remedy. To prevent injury to the. 
tree, a limb may be sawn off, leaving a small part, which can be used to strike against so as to jar the tree.

2. Gather and destroy the affected piums as they fall.

3. Spray Paris green, one pound to about two hundred and fifty gallons of water; especially if the foliage is tender, two pounds of lime added will prevent injury to the leaves. Spraying once before the trees bloom, as som as foliage is well started, again as soon as the petals faii, and repeat about a week later.

Wireworm-Click Beetle (Agr-iotes).

The egrs are usually laid in grass-land.

The larva is several years in developing, generally three. As there are several species that are known as wireworms, we shall give the general character of the larva: Long, slender, one-half to one inch in length, yellowish-brown, hard and wire-like, with six legs at one end. They attack the roots, about one inch below the surface, and burrow deeper during winter. Melanotus communis and Agriotes mancus are among the most common; the former are about one inch long and twice as thick as the latter, which is not over half an inch in length. 
The fupa stage is entered in early fall, and soon changes to a beetle. At this stage the insect is very tender, and does not leave the cavity in which it was pupa until spring.

'The imaso is a dark gray beetle, in most species, and when placed on its back is able to spring over with a sort of click; hence, the name "click-beetle" is sometimes given to this insect.

The larva of these beetles do great damage to grasses, grains, corn, and potatoes. 'They are sometimes confounded witi contipedes and millipedes, both of which have many legs, while the wireworms have only six.

At Cornell Experiment Station, this insect was very thoroughly studied, and all the remedies known tried. The result was that scarcely one of them proved a success. One of the most important results attained by the investigations was that when the $i m$ arsoes are first developed in the pupa cells, they are very tender, and that if the cells in the earth be broken in the fall, the beetles die.

REMEDIES.

1. Fall ploughing.

2. Pieces of potato put in the ground will attract these worms, and if examined from time to time, will be found to contain wireworms, 
which may he destroyed. This is only practi. cable in gardens and small areas badly affected. A small stick may indicate where the potatoes are.

3. Salt has a tendency to drive the worms down into the ground, and thus give the crop time to make some headway and withstand the atlack.

White Grub, May Beetle (Lachnosternd fuscal.

'The egrss are laid at the roots of grass.

'The larva is a large, soft, white grub, about an inch and a-lalf long, usually curled at the posterior end. It takes three years to develop. and is sometimes very destructive in old passtures, and in gardens, to strawberry plants.

The futa is in the ground. The imargo, an inch long, is a large, plump, brown beetle, often observed buzzing around in the summer even. ings, about the end of May. It feeds upon the foliagre of the cherry and plum.

REMEDIES.

I. Spraying with Paris green, for the beetles.

2. In gardens, dig up the plants attacked and kill the grubs.

3 linli ploughing. 
4. Summer-fallowing. Many birds are very fond of these grubs.

\section{Rose Bug or Rose Chafer (Macrodactylus} subspinosus).

This insect attacks many plants, such as grape, rose, cherry, apple, plum, pear, and peach.

'The egrrs are laid beneath the surface of the ground, and hatch in about two weeks. The larua feeds on the tender roots of grass, etc.. and spends its first season in the ground, where it hibernates.

The pupa stage is entered in spring. The imago appears about the time the grapes are in blossom, and becomes a very serious pest. It is in this stage that the insect is most injurious. Fortunately, the beetle lives only a month. It is about half an inch long; has a slender body; long, sprawling legs, and is of a brownish color, covered with a sort of yellowish-gray down that can be rubbed off. 'This is a difficult insect to overcome.

REMEDIES.

I. Spraying with a mixture made from three or four pecks of freshly-slacked lime, and one quart of carbolic acid, in fifty gallons water.

2. Kerosene emulsion. 
3. Jarring the vines attacked, in the morning, will secure many.

\section{Round-headed Borer (Saperda candida).}

The esgrs are deposited about Jume, near the base of the trunk of the apple tree. The larwa eats its way through the outer bark to the inner, and takes about three years to develop. It works in the sapwood, where it forms that, shallow cavities, filled with sawdust-like castings. These are often seen on the bark, and indicate where the "borer" is at work. As it reaches maturity, it cuts a passage upwards into the solid wood, and then curves towards the bark. In this channel it enters the pupa stage, about spring. When fully developed, it is an inch long, with a round head that distinguishes it from the flat-headed borer, which also affects the apple iree.

The imago is a slender beetle, one inch lor $r$, with two broad, whitish stripes on the wing covers, and long jointed antenne. It appears about June.

REMEDIES.

I. Examine the trees in autumn, and where the sawdust-like castings indicate the presence of the "borer," a stiff wire may be pushed in 
and the larva killed, or sometimes the larva can be cut out with a knife.

2. About the begimning of June, apply the following mixture to the trunk of the tree :One pound of hard soap, or one quart soft, in two gallons of water; heat to boiling, and add one pint crude carbolic acid; make a second application in three weeks. 'This can be well done by using an old scrubbing.brush to rub it in.

\section{Flat-headed Borer (Chrysoliothris femorata).}

'This insect also attacks the trunk of the apple tree, but lays its esrors higher up the tree than the preceding one. The larva is a pale yellow, an inch long, and has a well-marked flat head, much wider than the body. It is sometimes found even in the limbs, and is not so long in developing as the round-heacled borer. Ii cuts flat chammels in the sapwood, and sometimes girdles the tree. Castings and discolored bark indicate its presence. It finally bores into the solid wood, and becomes a pupa for about two weeks, and then emerges as an imago about half an inch long, somewhat flat, and of a greenish-black color, with three raised lines on each wing-cover. The legs and under side of the body present a coppery instre. 


\section{REMEDIES}

Are the same as for the round-headed borer.

\section{Clover-root Borer (Hylaste's trifolii).}

The esors are deposited at the crown of the root. 'The larva, about one-eighth of an inch long, burrows down into the root, where, after a time, it becomes a $p u p a$.

The imago is a short, thick-set, brownishblack beetle, one-tenth of an inch long. It may spend the winter as larva, pupa, or imago. It is in the second year of the clover that it becomes most injurious.

REIEDY.

I. Mow the clover but once, and pasture or plough under the second growth. Frequent rotation of the clover crop seems to be the only preventive.

\section{Spotted Pelidnota (Pelidnota functata).}

This large brown beetle, one inch long, with three ilack spots on each wing-cover-one on each side of the thorax and one in the centrepreys upon the grape. On the under side of the body it presents a green, metallic lustre. As it is never very numerous, it may be hand-picked and destroyed. 
Goldsmith Beetle (Cotalpa lanigera).

This is another large beetle found upon the grape, and is about the same size as the preceding one. The wing-covers are a light yellow, the edges and beneath the body are of a metallic lustre. This is not a seriois pest, and may also be hand-picked.

\section{Grain Weevil (Calandria sranaria).}

This insect is a very small beetle, one-eighth of an inch long, found among grain in the granary. It has a well-marked snout, and is of a brownish color. The writer had several specimens sent him from different parts of Ontario during I 894 , showing that it is more common than formerly.

\section{REMEIS.}

The best remedy for this and ail other pests aliong stored grain is carbon bisulphide. The grain may be put in a barrel, and the liquid poured into a saucer placed on the grain, then cover the whole so as to keep in the vapor, which will sink down among the grain and kill every insect. One ounce is about enough for one hundred pounds of grain. It must be remembered that vapor of this substance is very inflammable. 


\section{CHAP'TER VIII.}

InJURIOUS INSECTS IN THE ORDER LEPIDOPTERA.

This very extensive order, embracing the moths and butterflies, contains many enemies to the fruit grower and vegetable gardener. Many of the larva of these insects are voracious feeders upon the foliage of trees and other plants. The different stages in development are very marked in this group.

\section{Plum Sphinx (Sphinx drupifer(arum).}

The esrrs are deposited singly upon the leaves. 'The larya is fully three inches long and thick in proportion, of apple-green color, with seven oblique white bands on each side, bordered in front with light purple.

The air spiracles or breathing pores on the side of each segment are very marked. A long, horn-like structure is on the last segment. The brown pupa-case in the ground is naked, and has a short tongue-case. The imaso is a large, grayish-colored moth, with strong wings tapering to a point, which, when expanded, are three and a-half inches across. 
REMEDY.

I. Hand-picking, as there are not likely to be many, and they are readily seen.

\section{Tomato Worm (Phlegathontius celcus).}

the

The esiss are deposited on the leaves of both the tomato and the potato. 'The larra is three inches long, and has a horn-like structure on the last segment, and the breathing pores are very distinct. The general color is a light green, with oblique whitish bands on each side.

The pupa case resembles that of the plum sphinx, but has a mucin longer tongue-case, and is also in the ground.

aves.

hick

The imagro is a large, gray moth. with five orange spots on each side of the body.

even

REMEIYY.

Hand-picking, or Paris green.

the Grape Sphinx (Darapsa myron).

'This sphinx preys upon the grape. The larva, two inches long, with red feet, is pale green, with pale yellow stripe down each side. Seven spots, varying in color, are along the back.

The pupa is in a cocoon,tormed by a few leaves being drawn together. The imago appears about May. 'The spread wings measure about two 
and a half inches; the fore wings are dark olivegreen, crossed by bands of greenish-gray, while the hind ones are reddish.

REMEDY.

Hand-picking.

\section{Philampelus achemon, Thyreus Abbotii, Deilephila lineata.}

Also large sphinx moths found upon the grape from time to time, but are not very common. A minute description of any of these moths in the family Sphingidx would require too much space for an elementary work of this kind. Consequently, only a few species have been selected and briefly described--sufficiently, we think, to enable them to be identified. Where larve are large, they are not usually numerous, and therefore may readily be got rid of by hand-picking. Cutworms (Asrotis, Mamestra, Hadena).

The cutworms which are generally found doing so much damange to garden crops, usually belong to one or other of the above generamany of them to Agrotis. As their characters are much alike, we shall refer to them in general terms. The larece are about one and a-half inches long; smooth, naked, and preseuting a greasy-looking appearance. 'The color varies, but is generally sone shade of green, gray, 
brown, or black, and most are night feeders. When disturbed, they curl up at both ends. Scme confine their ravages to the ground, and are kncwn as the "ground cutworms." Among the nost common are Agrotis ypsilon. A. subsothar, A. tesselata. Others, which defoliate trees, are termed "climbing cutworms," the most common being A. sancia, A. Cochranii, A. scandens, A. claudestina. The pripa stage is passed in the ground. The moths appear in midsummer. Most have the front wings of a mottled gray appearance, with some spots; the hind wings are of a much lighter color. The expanded wings measure one to three inches across.

\section{REMEDIES.}

I. Paris green,sprayed upon trees attacked by the "climbing cutworms." will be successful.

2. In gardens, poisoned baits may be successfully used, such as small bunches of clover, cabbage leaves, etc., dipped in Paris green solution (one pound Paris green to one hundred gallons water), and placed near the attacked plants. The cutworms will feed upon these and be destroyed.

3. When putting out cabbage or tomato plants, they may be protected by putting a piecé 
of paper around them in such a way as to prevent the worm getting at the stem.

4. Dig out the worms and destroy, where plants have been eaten.

Io Emperor Moth (Automeris Io).

This insect is found, sometimes, upon the cherry, but is not a serious pest. It is referred to here merely on account of its being such a conspicuously marked, and beautiful moth.

'The moth appears about June. It measures two and a-half inches across the expanded wings, which are of a deep yellow color, in the male, and in the female (much the larger-three and a-half inches across) of a purpiish-brown. The hind wings in both have, near the middle, a large, round blue spot, with whitish centre. Promethea Moth (Callosamia promethea). The larva of this large moth is sometimes found upon the cherry and poplar, but is not very troublesome.

The larai, very marked, is two inches long, bluish-green, with eight small warts of a deep blue color on each segment; the top of the third and fourth segments bears short coral-red horns, and near the end is a yellow horn.

The pupa is enclosed in a silken cocoon, which is very conspicuous, hanging from twigs 
by a slender, string-like structure two-thirds of an inch long. The imago differs in the sexes. The wings of the male are brownish-black; those of the female are light reddish-brown; both have an eye-like, dark spot near the tip of the front wings, which measures three-quarters of an inch across.

\section{Cecropian Moth (Samia cecropia).}

This is one of our largest moths. The larva is sometimes found feeding upon the leaves of the apple, but it is so large that it is readily seen and may be picked off. The eggs of this insect are of considerable size and of a brownish color.

The larva is four inches long; pale green; the third and fourth segments bear coral-red warts, the others have yellow, except those on the second and last, which are biue. It is about an inch in diameter.

The pupa is in a cocoon fastened to the side of a twig. The cocoon consists of an outside tough layer, and an inside loose one. It is three inches long.

The imago is a very large and beautiful moth, measuring from five to seven inches across the expanded wings. The wings are brown, the front being somewhat reddish. Near the mid- 
dle of each is a kidney-shaped white spot. The front wings, near the tip, have an eye-like spot, and near the shoulder are of a dull red color.

RENIEDIES.

r. Hand-picking.

2. Gathering the large cocoons readily seen on the trees.

\section{Polyphemus Moth (Telca polyphemus).}

This is another large and beautiful moth, resembling the Cecropian, but is yellowish-brown in color, and not quite so large.

The egros are large and crcam-colored. The lavalu, usually upon the plum, is three inches long, and much thicker in the middle, tapering towards each end ; this serves to distinguish it from many of the other laruce, which are about. the same thickness the whole length of the body. There is a V-shaped band on the last segment. The pupa is in a compact cocoon, with some leaves interwoven in it, and is of an oval outline. It usually is found upon the ground.

The imago is a large, ochre-yellow colored moth, five to six inches across the wings. An eye-like spot is near the middle of each wing, bordered with yellow. 
The spot, lor.

seen

moth, brown

The inches pering uish it about of the le last jcoon, ; of an in the

olored An wing,

REMEDY.

1. Hand-picking. A large Ichneumon (Ophion macrurum) frequently preys upon the iarva of this and the Cecropian moth.

\section{American Tent Caterpillar (Clisiocampa Americanca).}

The $e_{\text {gogs }}$ are deposited on small twigs, in ringlike clusters, oval in outline, two to three hundred in a mass, and the whole couted with a sort of varnish.

The larva is hairy, with a white stripe down the centre of the back, and is two inches long. They construct " tents," or silken webs, in the forks of the branches; these they leave, morning and evening, to feed upon the foliage of the trees attacked (usually the apple). The pupa is in a cocoon, generally found beneath the topboard of fences and similar places of shelter. The covering consists of two layers, with a sort of sulphur-like substance between. The imagro is a reddish-brown moth, with two oblique whitish lines across the wings, which measure one and a-half inches when spread. Clisiocampa sylvatica, the forest tent caterpillar, is another species in the same genus, found also preying upon the foliage of the apple tree. The principal points of difference are : The egg-mass 
is not oval in outline, but is cut off squarely at each end; the larva, instead of having a white line down the back, has a series of white dots, and the oblique line on the wings is darker than in the precerling; otherwise the two species bear a close resemblance to each other in appearance and habit. They feed upon several forest trees as well as on the apple.

\section{REMEDIES.}

I. Collect and destroy the egg-clusters in winter.

2. Crush the "tents" when full of caterpillars.

3. Apply Paris green.

Tussock Moth (Notolophus leucostigma).

The egrrs are in clusters on dried leaves, which remain attached to the tree. 'The larva is an inch long, yellowish, and hairy; the head and two wort-like structures are red; these are followed by four cream-colored tufts along the back. 'Two long black plumes project forward and backward. It feeds on the apple and some shade trees. The pupa has two forms: that of the male, small and pointed ; that of the female, larger, and usually near the eggs. The imaso differs very much in the sexes: the female is wingless, while the male has wings of an ashengray color. A small black spot occurs on the 
rely at white dots, er than s bear ippearI forest ters in pillars.

r).

leaves, larva ie head ese are ing the orward d some that of female, imago male is ashenon the

outer edge, near the tip, and a small moonshaped marking near the outer hind angle. The wings, spread, measure one and a-quarter inches. The female, shortly after emerging from the pupa, lays her eggs on or near the old cocoon.

REMEDIES

I. Collect the eggs and destroy them.

2. Paris green, sprayed.

Codling Moth (Carpocapsa pomonella).

The egrgs are laid on the calyx of the young apple, while it is turned up. The larva is half an inch long, and burrows its way into the apple, where it feeds till fully developed, then crawls out to enter the pupa condition, which lasts two weeks. Affected apples fall to the ground, and often contain the worm in them, but it generally leaves the apple before this.

The cocoons are frequently under the bark, and other sheltered spots. 'The writer has found as many as ir 8 under a band of tow placed around the trunk of the tree to catch the larvæ after leaving the apples.

The imago is a tiny moth, the front wings ashen-gray, the hind ones light, with a satin lustre. Though there must be many, still they are seldom seen. 
It appears about the time the trees are in bloom, and is one of the worst pests that attack the apple.

REMEIIES.

I. lieed to hogs the fallen apples, which may contain the larvic.

2. 'Trap the larve, crawling "1p) and down the trunk, by bands of rough cloth, or tow, under which they will crawl and spin their cocoons.

3. Paris green, sprayed; first application, as soon as the blossoms fall; second, eight to twelve days after ; third, when the fruit is from one-quarter to one-half inch in diameter.

\section{Cabbage Worm (Pieris rapce).}

The egrgs are laid upon the leaves. The larva is.an inch and one-half long; it is greenish, with a light yellow line down the back and along each side. It matures in two weeks, and there are several generations in a cocoon.

The pupa is naked, and usually under fence-boards, and in sheltered places, near where the caterpillar has been feeding. It is angular, and has a silken thread around the middle, suspending it. This condition continues about ten days. The imago is a common whip butterfly, found tlying about gardens. It $h$ few black markings. 
The female has two spots near the middle of attack

hay

wn the under coons. ion, as ght to $s$ from

The greenck and s, and under

near It is and the ntinues whito each front wing, while the male has only one. The wings, expanded, measure two inches across. REMEDIES.

No insect has had more remedies published for its destruction than this.

I. Pyrethrum powder mixed with six to eight parts flour, and dusted upon the plants, is one of the best. Some use it in solution: one ounce pyrethrum to three gallons of water.

2. Water, $130^{\circ} \mathrm{F}$., applied, will kill the worms . and not injure the cabbage plants.

3. Paris green on young plants.

4. Kerosene emulsion, until the plants are heading.

Cankerworm (Anisopteryx vernata).

'This insect attacks the apple, plum, cherry, and basswood, but is usually found on the apple. There are two species: one, the above, appearing in spring, is known as the "spring cankerworm," and one, in the fall, as "fall cankerworm."

The egrs are laid in irregular masses, upon the twigs. The larva varies much in color in each species, from a greenish-yellow to a dark brown. It is slender, an inch long, and moves with a loop-like motion; hence, the term "meas- 
uring-worm" sometimes is used. Having fully developed, it passes to the ground, where it enters the pupa stage. It can drop from the trees by a silken thread. The imago appears in spring. The female is without wings. The male is ash-colored, and has wings. $A$. pometaria is much the same as the preceding, but the imago appears in the fall. The wingless females in both species crawl up the trunks to lay their eggs on the twigs.

\section{REMEDIES.}

I. Use means to trap the climbing females. This may be done by putting a band of some material, smeared with tar, around the tree, or using what are known as "tree protectors," a sort of funnel-shaped structure, that is fastened around the tree, three or four feet from the ground; these prevent the females from getting up the tree.

2. Paris green will destroy the larvæ feeding upon the foliage.

\section{Army Worm (Leucania unipuncta).}

The egg's are laid at the roots of grass, usually in low-lying spots. The larva is a general feeder upon wheat, grass, oats, etc. They frequently move in great numbers, devouring everything green on the line of march. It is 
one and a-quarter inches long, with three narrow, yellowish stripes along the back, and develops in four weeks. The pupa is in the ground, but sometimes on the surface.

The imago is a gray-colored moth, with a small white spot near the centre of the front wings, which measure one and three-quarter inches across. ' $t$ may pass the winter in the halfgrown caı_rpillar, or larval condition, or as a moth. During the summer of '94 they were plentiful in several parts of Ontario.

\section{REMEDIES.}

I. Spray the edge of the field, where it may be safely done, with Paris green, as the "army" of worms advances to feed upon it.

2. Plough a furrow between the field and the approaching worms, and have the perpendicular side next the crop. As the worms advance, they cannot get over the furrow for a time, and may be killed by thousands while in it.

3. Form windrows of straw, and as the worms get into them, set fire to the siraw.

4. Burn over pastures and meadows in the spring and fall. As the insect breeds largely in rank grass (such as is seen bordering swamps), these can be burned 
Fall Webworm (Hyphantria cunea).

The egrss are laid in patches on the under side of leaves, near the end of a branch.

The larvæ spin a web over them as they feed, covering themselves and the leaves they are feeding upon. This is sometimes quite large, and is readily seen towards the close of summer. The larva, when developed, is an inch long, the body thickly covered with yellowish hairs in tufts. It feeds on the cherry, apple, and pear. The $p u p a$ is in the ground, or beneath something on the surface. The imago is a pure white moth, measuring a little over an inch across its expanded wings.

REMEDIES.

I. Cut off the web and destroy the caterpillars.

2. Spray with Paris green.

Celery Caterpillar (Papilio asterias).

This is a very beautiful, swallow-tailed butterfly, found feeding upon celery, parsnip, carrot, and parsley. The egrgs are deposited on the leaves. The larola (one aind a-half inches long) is very marked, with yeilow and black lines crossing the body, which is of a general pale green color. It has a pair of peculiar, horn-like structures just behind the head; these can emit an unpleasant odor. 
The $p u p a$ is in a sheltered position, and is suspended by a silken thread, passing under it and attached to the board, etc., where the chrysalis is located. The imago is a very beautiful butterfly, black, and handsomely marked with yellow and blue markings. The wings measure two to three inches across, and have a swallow-tail appearance.

REMEDIES.

I. Hand-picking. larvæ.

2. Dust pyrethrum powder on the young

$P$. turnus resembles the above, but its prevailing color is yellow, instead of black; in size and form, it is much the same, but feeds on the apple.

\section{Peach Borer (Sannina exitiosa).}

The egrgs are laid on the bark or in crevices on the surface of the ground. The larva, a whitish caterpillar with $16 \ldots \mathrm{s}$, bores into the wood, and works downward into the larger roots; a few hairs on tubercles are scattered over the body. The pupa is in the tree, within a rudely-constructed cocoon. The imago is a small moth, with transparent wings and wasplike body. 
REMEDIES.

I. Cut out the borers in fall or spring. Their location may be seen by removing some of the earth from the base of the tree.

2. Remove the earth and apply boiling water.

3. Mound up the trees (one foot) late in spring, and remove the soil in September.

4. One bushel of lime, one bushel of ashes, and one pint of crude carbolic acid, with thirty gallons water, make an excellent mixture to apply upon the trees. In using this, remove the earth and apply it for about two feet up the trunk, in the end of May or beginning of June.

Aegeria rubi is a moth which bears a close resemblance to the preceding; it affects the canes of the raspberry, by depositing its eggs in them jist above the ground. These give rise to borers, which are sometimes very injurious. About the only treatment for this is to cut out the "borer," or pull up and burn the attacked canes.

Apple Bucculatrix (Bucculatrix pomefoliella).

This is a small but beautiful moth, with narrow, much-fringed wings; sometimes injurious to apple trees. The cocoons are very small 
(half-inch), white and ribbed, and occur in numbers upon the under side of twigs. They have been quite common lately in many orchards.

REMEDIES.

I. Remove the cocoons in winter. Although small, they can easily be seen upon the twigs.

2. Paris green will destroy the larva, if applied as soon as the petals fall.

\section{Yellow-necked Caterpillar (Datana min- istra).}

The larva of this insect usually appears upon apple trees in the early part of the summer. They feed together in considerable numbers, and when disturbed or at rest they assume a peculiar position-something of an imploring attitude. They are striped along the body. The imagro is a moth with light-brown wings, striped across with brown of a darker shade. It measures two inches across the expanded wings.

\section{REMEDIES.}

1. Cut off twigs containing a crowd of larva and destroy them.

2. Spray with Paris green.

Yellow Woolly Bear (Spilosoma Virginica).

This white moth, which is sometimes, in the larval condition, found feeding upon the grape, 
resembles the imago of the "fall webworm" upon the apple, but is larger, and has some black dots on its wings. It does not occur in such numbers as to do much injury.

Red-humped Caterpillar (Oedemasia concinna).

The larvi of this moth is found on the plum, cherry, apple, and pear, and sometimes does considerable damage. The larva, an inch long, is easily identified : the head and a hump on the fourth segment are red; narrow black, yellow and white lines extend along the body; two rows of black prickles along the back, and shorter ones along the sicles. The pupa is in the ground, or beneath leaves. The imago is a moth, with front wings of a brown color on the inner margin, and grayish on the outer, with a dot near the middle, and a spot near each angle of the hind wings.

$$
\text { REMEDY. }
$$

I. Spray with Paris green.

\section{Bud Moth (Tmetocera ocellana).}

'This insect is found attacking the buds upon the apple, and sometimes proves very injurious. The half-grown larva winters over, and appears in spring as a small brown caterpillar, just about the time the buds begin to open, and 
feeds upon them. It measures about half an inch when full-grown. By rolling up one side of a leaf, and securely fastening it with silken threads, it forms a tube, in which it enters the pupa stage, having lined the little chamber with a closed woven layer of silk. 'This condition lasts ten days. The imaso is a small moth, resembling the codling moth in size and form. It is of an ash-gray color. The front wings have a whitish-gray band across the middle; the hind wings are a dusty brown. The expanded wings measure half an inch across.

REMEDY.

I. Spray Paris green (one pound to two hundred and fifty gailons of water) just as the buds are opening, and again in scven to ten day, or before the blossoms open. 
CHAPTER IX.

Injurious Insects in the Order Hemiptera.

'This order embraces such insects as the plantlice and bugs. Most of the injurious insects of this division live on the juice of plants, upon which they feed. They may be destroyed by kerosene emulsion. The insects in this group do not pass through a series of well-marked changes, from the young to the adult form.

\section{The Squash Bug (Anasa tristis).}

The larva resembles the imagro, except in size. The adult insect is a rusty-black, flat bug, yellow on the under side, half an inch long, and has an offensive odor. It winters in the adult form, underneath leaves, boards, etc. The eggrs are laid on the under sides of the leaves, in June. They soon hatch out the young bugs.

\section{RENEDIES.}

1. Hand-picking, morning and evening, when they are less active.

2. Kerosene emulsion, diluted with twelve parts water, is effective.

3. Small boards placed in the vicinity of the plants become hiding places for them, and serve as traps beneath which many can be destroyed. 


\section{Aphidæ (Plant-lice).}

TERA.

plant-

ects of

upon

ed by

group

arked

l.

pt in

, flat:

long,

n the

The

es, in

gs.

when

velve

ff the serve yed.

These minute, greenish insects affect the foliage of nearly all plants. They present a strange peculiarity in their life-history. Those that appear in spring are females, and, generation after generation, they produce living young, all females, until the close of summer, when males appear in the last generation. Esgrs are now laid, and the following spring females appear to again produce living young for several generations. Many species of them secrete a sweet substance, of which ants are very fondso much so that they search for plant-lice in order to get it on the leaves near the lice. Ants are said to even carry the Aphidæe to their nests, and keep them there to supply the sweet liquid, and thus have them, as we keep cows to supply milik. Aphis mali infests the apple.

REMEDY.

I. Kerosene emulsion, diluted with ten parts water, sprayed, will destroy them. Plant-lice are often very troublesome in greenhouses, and are usually treated with tobacco smoke. Tobacco stems are put in a vessel and burned; the closed greenhouse becomes filled with the smoke, which kills the lice. Solution is another form in which tobacco is used to kill plant-lice; 
it is malle by putting one pound of tobacco stems, leaves or dust, into two or three gallons of water, and boiling it for about twenty minutes; as soon as cold, it is fit for use, and can be sprayed upon the plants with good effect. A. brassice appears on the cabbage; Myzus ribis, on the currant ; A. maidis, on corm; Myzus cerasi, on the cherry; $M$. persicce, on the peach; A.prunifolii, on the plum; Siphonophora arence, on wheat and oats. 'These are all memmers of the family Aphididce, and where practicable, are destroyed by kerosene emulsion, diluted with ten to fifteen parts water,or tobacco, in solution, or as smoke.

Oyster-shell Bark-louse (Mylilaspis pomorumi).

'The egrrs are beneath the oyster-shell shaped scale (one-sixth of an inch) upon the twigs and other parts of the tree, and are of much the same color as the young bark. They hatch in the end of May or the begiuning of June. The laruce are very minute, almost invisible, and appear as small specks moving on the twigs of the apple tree. As soon as hatched, they seek the erids of the young twigs, where they become fixed, and continue to suck the juice from the twigs. Soon a scale forms over them, by a sub- 
stance issuing from their bodies, in the form of waxy threads. All under the scales, the shape of an oyster-shell, are females that deposit their eggs under the scale. The scale covering a male is more oblong, and is very rarely seen.

\section{RENEDY.}

I. In winter, or early spring, scrape off the rough bark from the trunk and large limbs, and rub in with a scrubbing-brush the following solution :-One quart soft soap, or one-quarter pound hard, in two quarts boiling water; take seven parts of this and add one part carbolic acid; then, when the young lice are moving (May or June), spray with kerosene emulsion, diluted with ten parts water.

\section{Lice (Hcematopinus).}

Our domestic animals are often infested with lice. There are two types,-one suck, the other bite,-each belonging to a different order of insects; the first belong to the Hemiptera; the second to the Neuroptera, or Mallophaga, one of the orders into which the Neuroptera has been divided. The first are what we will now consider. They live upon animals, by sucking their blood. The eggs are stuck to the hairs, and soon hatch; the young lice resemble the 
adults, but are smaller. The following are the common species (all belonging to the same genus) :-

Hematopinus eurystinus, short-nosed ox-louse. II. vituli, long-nosed ox-louse.

H. asini, horse-louse.

H. suis, pig-louse.

H. piliferus, dog-louse.

REMEDIES,

I. Kerosene emulsion, ten to twelve parts water.

2. Rub with an ointment, three parts lard, one part coal oil.

3. 'Tobacco solution, one pound boiled in two gallons water.

Woolly Aphis (Schizneura lanigera).

This insect may appear on the tivigs or roots. When it appears on the twigs, it is in the axils of the leaf-stalks as masses of cotton-like material; this covers the young lice, and is - secreted by them. During summer most of these lice are wingless, and, like the other Aphide, produce living young.

Those that attack the roots cause knot-like structures that readily indicate infested roots. Both forms are very minute (one-tenth of an inch long). 
RE.IEDILS.

1. Pour scalding water on the roots, if the roots are exposed, as in transplanting; a temperature $120^{\circ}$ to $150^{\circ} \mathrm{F}$. is sufficient.

2. Kerosene emulsion will destroy those upon the limbs.

3. Refuse tobacco powder, worked in about the roots, is claimed to destroy the root form. Scurfy Bark-louse (Chionaspis furfurus).

'This resembles the oyster-shell bark-louse in its general life-history, but the scales are more oval, and slightly taper to one end; grayishwhite in color, and very minute (one-tenth of an inch). The scales of the males are more oblong. The egrgs beneath the scales hatch about the beginning of June, and the young lice proceed to suitable places, where they become fixed, and suck the juice from the small twigs.

REMEDY.

Sarne as for bark-lice.

San José Scale (Aspidiotus perniciosus).

This insect is attracting considerable attention at the present time. At first it was confined to California, but has now reached the Northern States, and may be expected in Ontario before long. It has also appeared in 
British Columbia. It attacks most fruit trees, and also currants. 'The scale is round, flat, and pressed close to the bark, which it resembles in color. It is very small (one-eighth of an inch in diameter). About the middle is a small, round, black point. 'This may appear yellowish. Sometimes the scales are very numerous, and overlap. The insects are half-grown in winter, but remain inder the scales till shortly after the trees leaf out.

REMEDIES.

1. About May-June spray with kerosene emulsion; dilute with nine parts water for apple trees ; peach, fifteen.

Make three applications, at intervals of ten days. In wirter an application may be made with stronger emulsion, diluted with four parts water.

Pear-tree Psylla (Psylla pyricolia).

The body of this minute insect (one-eighth of an inch long) is crimson, with black bands across; the wings are transparent, and, when it is at rest, slope over the body. When the leaves are attacked, they turn yellow, and the development of the fruit is arrested.

REMEDY.

Spray kerosene emulsion soon after the leaves unfold, and later, if the young insects appear. 


\section{Plum Seale (Lecanium).}

The brown scale of this insect, when fuily developed, is much larger than any of the previously described, being the fifth of an inch in diameter. The small scales move, about the beginning of April, making their way to the under side of the limbs. Here they remain, and mature, growing very rapidly uintil full development is attained at the end of May, when they begin to lay eggs under the scale. The matured scales are oval in the females, and much smaller and more oblong in the males, which last but a short time. The young insects appear about the first of July, proceed to the leaves, and locate themselves on the under side, to feed by sucking the juice. From this they emigrate, about September, to the under side of the branches, and hibernate, as small scales, less than the size of a pin-head, their growth being comparatively little during the summer. REMFDY.

Kerosene emulsion, applied as follows:-

I. Beginning of July, Kerosene emulsion diluted, six to eight parts water.

2. October, the same, but diluted only four parts water.

3. Some time in the winter, the same as No. 2. No. 2.

4. About the begining of April, the same as 


\section{CHAPTER X.}

Injurious Insects IN THE ORder Diptera.

In this order the insects have only two wings; the hind pair are lacking. Some small forms are very troublesome to field crops.

Wheat Midge (Diplosis tritici).

The egrs are deposited between the chaff of the wheat-heads during warm, damp evenings, and in the shade, about the middle of June. The larva is very small (one-eighth of an inch long), of an orange color, and feeds on the young kernel. Moisture is very favorable to its development, but it can remain for months in a dormant state, if the conditions are not suitable, and then become active when they are.

It remains in the head till the stalk is wet, and then passes to the ground, where it enters the pupa stage. The imago is a very small fly (one-tenth of an inch long), yellowish body, with two clear, glossy wings.

\section{REMEDIES.}

I. Sow early-maturing wheat, as the midge is less liable to attack it.

2. Ploughing deep in the fall buries many larva and pupæ. 
3. Screenings often contain pupæ, which may be readily destroyed.

4. Sow midge-proof wheat.

Fiessian Fly (Cecidomyia destructor).

This is another insect which attacks the wheat.

Fall wheat is very favorable for its development. 'The egrgs are iaid on the upper surface of the fall-wheat blades. As socn as the larace hatch they descend to the base of the sheath, where they vecome imbedded in the stalk. They take about three weeks to develop, and then hecome pupce, which resemble a flax-seed. The wirier is usually spent in this condition. In spring the imago appears, and lays eggs for another brood. The second brood is found higher up on the stem, at the first or second joints from the root. The imago is a minute, two-winged fly, with a dark-brown body and dull, smoky-brown wings.

REMEDIES.

1. Sow fall wheat as late as possible.

2. Burning the stubble of wheat fields may destroy many in the "flax-seed" condition.

3. Sow some wheat in the field early, so as to attract the fly, and after a time, when the eggs are deposited, plough this under and sow the regular crop. 
4. Burn any refuse which may contain the pupa ("flax-seed").

Clover-seed Midge (Cecidomyia legruminicola).

This insect lays its egrgs in the heads of the clover. The larva feeds upon the forming seed ; it is of an orange color, and very small (one-tenth inch long). The pupa is in the ground, or under rubbish on the surface. The imago is a very small fly, appearing about June and September.

\section{REMEIIES.}

1. Stop growing clover-seed, and thus raise no second brood.

2. Pasture the clover till the beginning or middle of June, and then let it grow for seed; this avoids the first attack.

3. Cut the clover before the end of June (when the larvæ are mature and enter the ground). This will destroy the first brood, and a second will not appear.

4. Now when the heads are green and just forming; leave this as a ulch; a new crop of blossoms will come between the regular crops and escape the midge. 


\section{Horn-Fly (Haematobia serrata).}

The eggrs are laid on the surface of the dung of cattle, and from these the larve are hatched, which, when mature, enter the ground to assume the pupa condition for a few days. The imago is a small fly, resembling the house-fly, but very much smaller. These flies settle at the base of the horn, so as to be beyond the reach of the animal. By inserting their beaks into the skin and sucking the blood from the wound, they irritate the cattle, and are especially troublesome to milch cows. More injury is sustained from rubbing by the cattle than from the bites of the fly. They take only three weeks to complete their life-history, and consequently there are several broods in the season. They furst appeared in Canada in 1892.

\section{REMEDIES.}

I. Rub points attacked, with fish-oil,to which a little carbolic acid has been added.

2. Apply kerosene emulsion, diluted with twelve parts water. A better emulsion is made by substituting fish-oil for kerosene.

3. Tobacco dust will also keep off the insects, by dusting it upon the back, tail and neck of the animal, and upon the base of the horns. 
Sheep Tick (Melophagus ovinus).

These insects differ from any we have referred to among the Diptera, as the esrgs and larve are within the female, and the pupo are deposited in the wool of the sheep. From these egg-like bodies, or pupie, the "tick" or imago comes; although without wings, still it possesses other characters which indicate that it belongs to the order Iiptera, but is a degraded form. The "sheep dips" of stockmen are effectual in destroying this parasite.

Cabbage Maggot (Phorbia brassica).

'This small, slender fly, resembling the housefly, lays its ergrs near the crown of the root. These give rise to small worms that bore into the root and feed upon its substance. The pupce are in the ground, and are brown, egg-like bodies.

\section{REMEDIES.}

I. When putting out the plants, a teaspoonful of carbon bisulphide poured into a hole, near the plant, will prevent the fly depositing its eggs.

2. Apply Kerosene emu!sion about the roots.

3. Coal oil, mixed with sand and then sprinkled near the plants. 
4. A piece of tarred paper, three inches square, cut so as to place the plant in the centre, forms an excellent protection. This may be done by cutting a slit into the centre. Place the paper about the crown of the plant, and this will keep the fly from depositing its eggs.

\section{Onion Fly (Pliorbia ceparum).}

Much the same as the preceding, but the eggs are laid on onion bulbs.

REMEDIES.

I. Remove the affected onions, which can readily be recognized from their sickly, yellowish appearance. These will have worms in them, which should be destroyed. onions.

2. Sprinkle Kerosene emuision near the

3. Change the onion-bed each year.

\section{Horse Bot (Gastrophilus equi).}

The eggrs are deposited on the front legs, etc., where the horse can lick them; each has a small lid.

The larva is in the stomach of the horse, which it has reached by the horse licking newlyhatched larve from the egys and swallowing them. It is of an ugly, grub-like form, an inch long, with eleven segments. Spines on each 
segment enable it to keep attached to the walls of the stomach; there are also two hooks at the head. It develops in three weeks, then is passed out of the horse, and enters the pupa condition in the ground. The imago is a large, coarse fly; the 'body of the female is wedgeshaped, while that of the male has a more rounded outline.

REMEDIES.

I. Remove the eggs.

2. Apply carbolic acid to the parts where there are eggs.

\section{0x Bot (Hypoderma lineata).}

This insect causes the so-called "warbles" of cattle, or boil-like swellings on their backs, in spring and early summer.

These eros are deposited on the back, and the larac burrows into the skin, and there produces the lumps seen upon cattle affected. These injure the hide and affect the quality of the beef. The larva is fully an inch long, and has the breathing-pores located in the posterior part of the body. They are near the opening of the lump or swelling. When matured, the larva gets out of the swelling, reaches the ground. where it passes the $p u p a$, and then emerges a coarse, hairy tly. 
walls is at $n$ is oupa irge, dgenore , in

ind roed. the fly.

I. Press out the maggot and kill it.

2. Smearing the back with fish-oil in autumn will kill the larva, and rubbing on the same in summer keeps the fly away. Almost any greasy substance rubbed over the lumps, so as to close up the openings, will kill the larva, by preventing them getting air.

\section{Sheep Bot (Cephalaemia ovis).}

The larve of this insect are in the nostrils of the sheep, and work their way into the upper part of the head, but not into the brain, as is supposed by some.

The pupa is passed in the ground, and not in the head, from whicl: the larva pass when matured.

The imaro is smaller than the ox-fly.

REMEDIES.

I. Smear the nose with tar; this keeps away

2. Larvie in the nose may be killed by pushing up a feather, dipped in a weak solution of carbolic acid, or in turpentine.

Crane-Fly (Tipula oleracea).

These egros are laid in autumn, in the ground, or on the surface in low places; they are black and shining. The larva is legless, grayish, and 
wrinkled, one inch long; the tail ends abruptly, and has four tubercles above and two below. The pupa is in the ground; it has spines which enable it to rise out of the ground by wriggling up when developed. The imago resembles a very large mosquito, and appears about the end of summer, in low-lying spots. Wet weather is favorable to the development of the crane-fly. REMEDIES.

I. Mow neglected ground and burn rubbish, so as to destroy the sheltering places of the insects, and also any eggs which may be laid in such places.

2. Sow as late as possible; the pupa condition is entered about the middle of May.

3. Summer-fallowing and draining lessen the conditions favorable to their development. 


\section{CHAPTER XI.}

INJURIOUS INSECTS IN THE ORIER ORTHOPTIERA.

This order has comparatively few injurious insects, but those have heen in some cases a great source of injury. The young are much the same as the adult, except in being wingless, ind of smaller size.

\section{Rocky Mountain Locust ( Melanotlus} spretus).

The egros are laid in the ground, usually in such places as the roadside. The larva undergoes several moults before full development is reached. 'There appears to be seven stages in development: One in the egg, two in the larva, three in the pupa, and one in the imagro. The imaso is migratory in its habits; has long wings, and resembles our form $M$. femur. rubum (our common red-legged grasshopper), but the latter has much shorter wings. This insect, properly speaking, is a locust, and what is usually called a locust (tlie grecn locust) is a grasshopper, but the term grasshopper has been so long in use that it is likely to be still applied in the same way. 


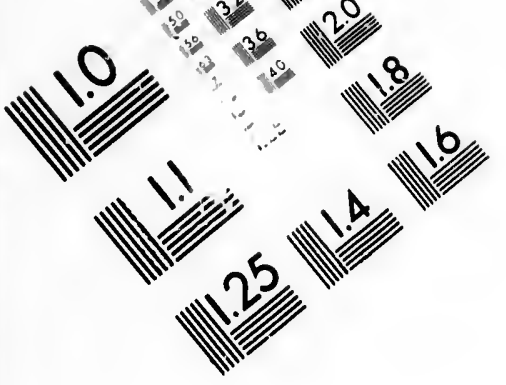

\section{IMAGE EVALUATION \\ TEST TARGET (MT-3)}
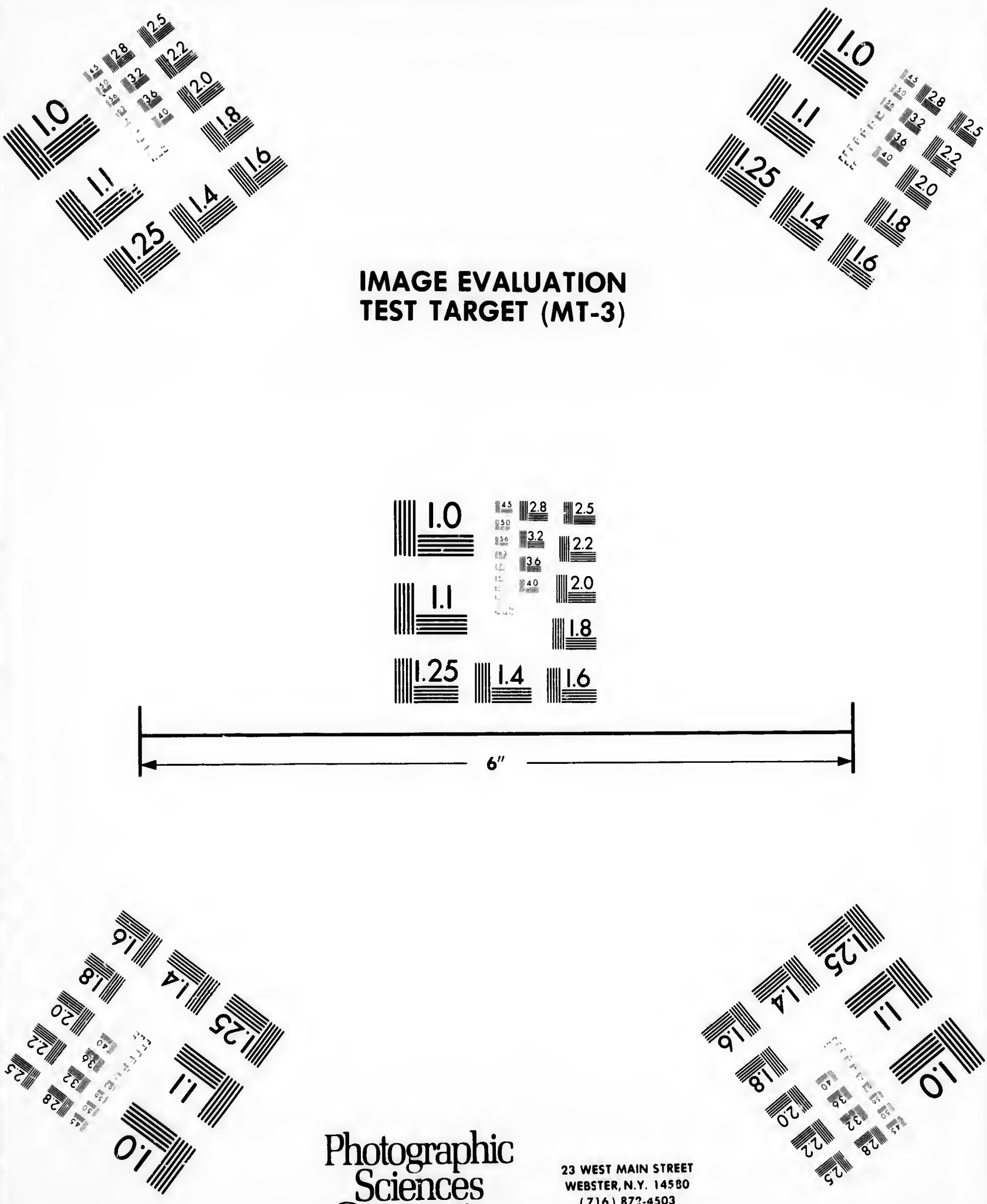

Photographic Sciences Corporation

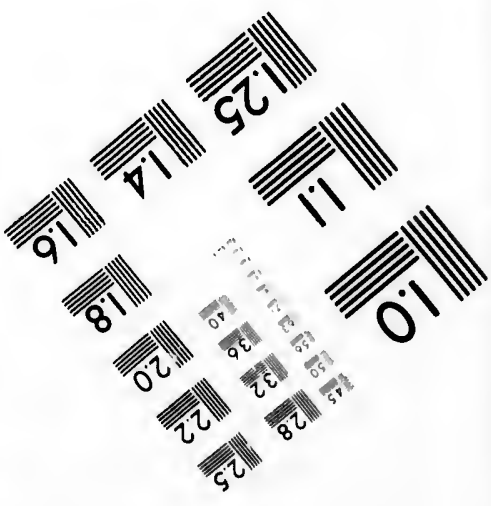





\section{REMEIIES.}

1. Put straw in heaps, and as the grasshoppers light upon them, set fire to the straw.

2. Use a "hopper doser." This is a pan, something like a scraper, and may be of the following size or larger: Eight feet long, one foot wide, one foot high at the back, and one inch at the front, with sloping sides. In the bottom of this is placed some tar or cnai oil, and the apparatus drawn over the fields when the grasshoppers are young. They jump into it by thousands and are killed.

3. Some make a mixture by weight: five parts brall; sugar, one; arsenic, one ; mix the bran and arsenic first, then add the sugar dissolved. Place this in spots near where the grasshoppers are. They will feed upon it readily. Some make the poisonous mixture by mixing one hundred pounds bran, two quarts molasses, and three pounds Paris green; a little water may be added.

4. Harrowing in autumn, or ploughing, will exposse the eggrs.

5. Ditches are sometimes dug, so as to catch the insects, which are killed as they collect - in them. 
BONOMIC FNTOMOIOG.

\section{Tree Cricket (OEcantlius niz'cus).}

'This insect lays its esgrs in rows one to two inches long, in the canes of the raspberry, during aurumn. The puncturing of the cane niakes it weak and easily broken. It does not feed upon the raspberry foliage, and is only troublesome as far as it injures the canes by depositing its eggs.

The adult is a pale green cricket, three-quarters of an inch long. It feeds upon plant-lice and other insects, and, to some extent, is beneficial.

REMEDN.

1. Cut out the affected canes and destroy the eggs. 


\section{CHADTER XII.}

INJURIOUS INSEC'S IN THE ORdER NeUROPTERA.

'This order is also one with but very few injurious insects; those that we refer to here are by some writers put into another order: Ma!lophaga (mallos, wool; pluagein, to eat); one of the eight orders into which the Neuroptera has been divided.

\section{Bird Lice.}

There are several species of these insects that attack the domestic animals, but nearly all belong to one genus: Trichodeites, T. parumpilosus, upon the horse; T. sphcerocephalus, on the sheep); $T$. scalaris, on cattle ; T. latus, on the dog; Menopon palliatum, on the hen.

'They do not feed by sucking blood, but upon wool, feathers, epidermal scales, etc., and have strong biting jaws. 'They are peculiar to birds, and hence spoken of as "bird-lice." They lay their eggs on the hair, etc.

KEMEIIES.

1. The same as those given on page $6 \mathrm{~s}$, for lice, and the following:-Four ounces stavesacre (powdered), four ounces soft soap, one 
ounce carbolic acid, one gallon of water, boiled half an hour, and applied weekly, is recommended by some as effectual.

2. One pound of lard, mixed with two ounces powdered sulphur, then add quarter-pint of kerosene, is reported as goud to rub on poultry. 3. Dust pyrethrum powder upon the infested parts of hens, and rub, from time to time, their perches with coal oil. 

NOTES. 


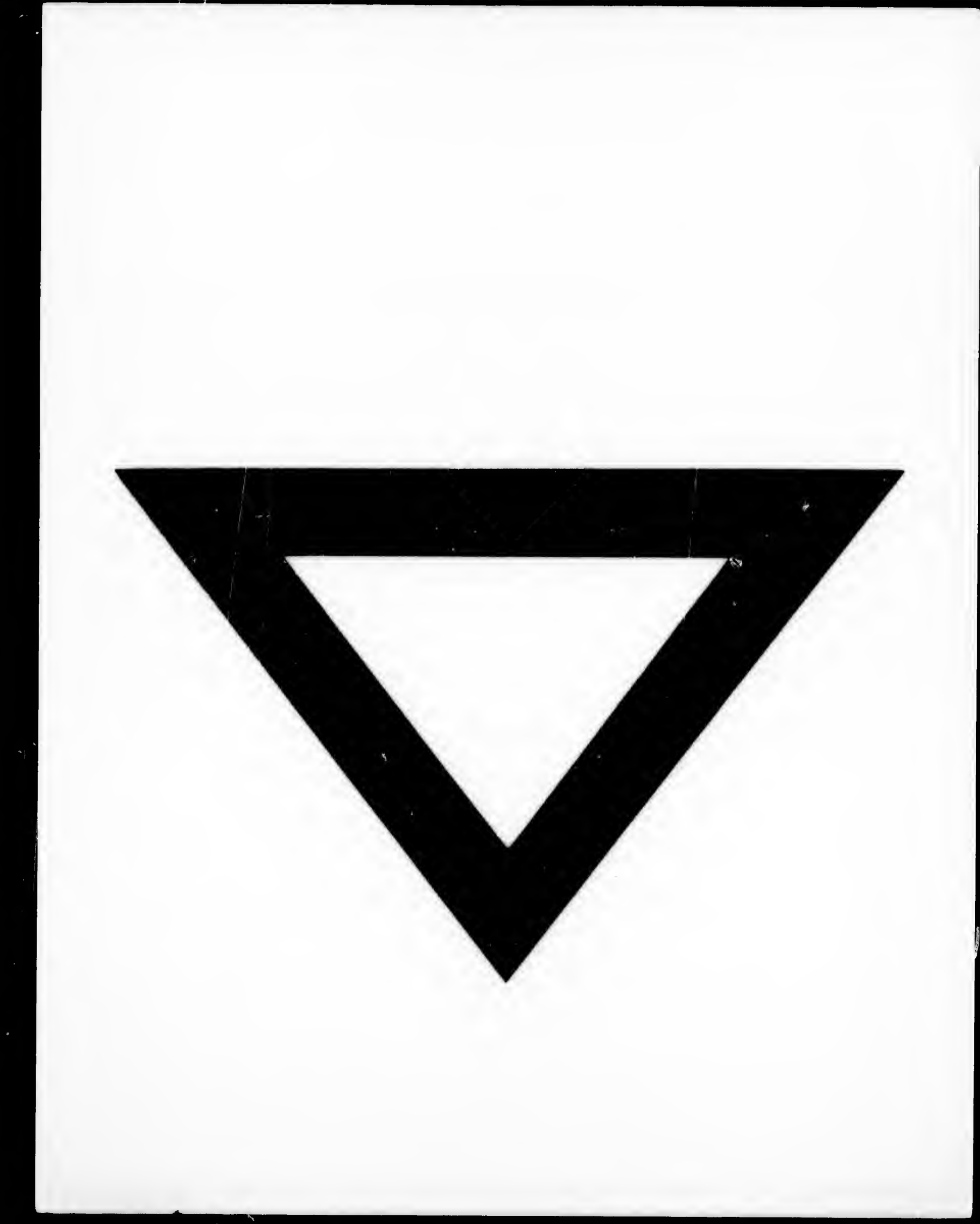

